\title{
Using an integrated approach to assess the sediment quality of an estuary from the semi-arid coast of Brazil
}

\author{
Ivanildo Surini Souza a,b,*, Giuliana Seraphim Araujo c, Ana Carolina Feitosa Cruz c, \\ Tainá Garcia Fonseca c,d , Julia Beatriz Duarte Alves Camargo ${ }^{c}$, \\ Guilherme Fulgêncio Medeiros ${ }^{\mathrm{e}}$, Denis M.S. Abessa ${ }^{\mathrm{a}, \mathrm{c}}$ \\ a Ceará Federal University - UFC, Institute of Marine Sciences, Av. Abolição, 3207, Fortaleza, CE 60165-081, Brazil \\ ${ }^{\mathrm{b}}$ Rio Grande do Norte Federal Institute for Science and Technology Education - IFRN, Av. Senador Salgado Filho, 1559, Natal, RN 59015-000, Brazil \\ c São Paulo State University - UNESP, Praça Infante Dom Henrique, s/n., São Vicente, SP 11330-900, Brazil \\ d Centre for Marine and Environmental Research - CIMA, Faculty of Sciences and Technology (FCT), University of Algarve, Campus de Gambelas, Faro 8005-139, Portugal \\ e Federal University of Rio Grande do Norte - UFRN, Campus Universitário Lagoa Nova, 1524, Natal, RN 59078-970, Brazil
}

\section{A R T I C L E I N F O}

\section{Article history:}

Received 29 August 2015

Received in revised form 8 January 2016

Accepted 1 February 2016

Available online 15 February 2016

\section{Keywords:}

Geochemistry

Contamination

Toxicity

Semi-arid coast

Sediments

\begin{abstract}
A B S T R A C T
The Jundiaí-Potengi Estuary (JPE) on the semi-arid coast of Brazil is influenced by multiple sources of pollution. Sediment quality at $10 \mathrm{JPE}$ sites was evaluated through an integrated approach. Rainy and dry seasons were considered. Collected sediments were analyzed for texture, metal, nitrogen, phosphorus concentrations, and toxicity to invertebrates. Geochemical and ecotoxicological data were integrated using qualitative approaches and multivariate techniques. We observed decreased sediment quality in both seasons, particularly in the midestuary. In the dry season, the contamination-toxicity relationship was clearer, as hydrological conditions favor contaminant retention within the estuary. Rainy season conditions were found to be worse, since stormwater drainage from agricultural and urban areas carries the contamination into the estuary. Because of the contamination sources and dissolved and particle-bound metal transport, contamination and toxicity did not correlate as clearly in the rainy season. The results suggest that unmeasured contaminants are contributing to JPE sediment degradation.
\end{abstract}

(c) 2016 Elsevier Ltd. All rights reserved.

\section{Introduction}

The majority of world's population inhabits coastal areas. As a consequence, the natural environments of these areas have been continuously altered and replaced with industrial facilities, ports, aquaculture ponds, agricultural fields, and urban expansion (Diegues, 2001; Chen et al., 2004; Marshall et al., 2010; Souza and Silva, 2011). Rapid population growth, the disordered occupation of coastal areas, and an economic model based on the consumption of natural resources have all caused the deterioration of these areas. The discharge of chemicals into the environment is one of the main threats to coastal and marine ecosystems. These pollutants include nutrients, pesticides, metals, detergents, oil, plastics, pharmaceuticals and personal care products, among others (Petrovic et al., 2003; Marins et al., 2004).

Despite the advances in environmental legislation to regulate emissions and reduce pollution, and in spite of the frequent insistence among scientists for the need to protect coastal zones, the release of contaminants into the sea and coastal water bodies continues, and

\footnotetext{
* Corresponding author at: Ceará Federal University - UFC, Institute of Marine Sciences, Av. Abolição, 3207, Fortaleza, CE 60165-081, Brazil.

E-mail address: ivanildo.surini@ifrn.edu.br (I.S. Souza).
}

many people and governments still believe that the world's coastal water bodies are capable of diluting contaminants to safe levels for both humans and biota (Zagatto and Bertoletti, 2008). This scenario has become a very problematic situation, especially in developing countries, where the establishment of new economic activities is often combined with ineffectiveness and inefficiency of their respective residue treatment systems and thus represents an emerging challenge to sustainable development (Choueri et al., 2009a; Torres et al., 2009).

Within the coastal zone, estuaries have been widely recognized as some of the most important and productive environments on the planet, as they provide different ecosystem products and services (Costanza et al., 1997; Savage et al., 2012). However, estuaries receive both the natural influences of continental terrains and that of human activity. Although estuarine degradation is a matter of global concern, the evaluation of the impacts on these environmental has not been an easy task (Chapman and Wang, 2001; Zonta et al., 1994, 2007; Elliott and Quintino, 2007), largely because estuaries may be susceptible to chemicals of different natures, and also because of estuaries high environmental instability.

Chemicals introduced into estuarine environments are influenced by a set of physical, chemical, and biological processes that may affect their fate and behavior (Chapman et al., 1999). Metals represent substances 
of special interest because they cannot be destroyed and may persist in the environment (Tam and Wong, 2000; Nicolau et al., 2006; Yang et al., 2014). After settling in sediments and waters, metals can be incorporated by the biota and easily spread along the food chain; during this process, these contaminants may have toxic effects on a wide range of organisms.

Most contaminants that are released into estuaries accumulate in the sediments (Bartoli et al., 2012); thus, sediments become not only a repository but also a source of contaminants for the water column and the biota (Adams et al., 1992; Nipper, 1997; Delvalls et al., 2004; Burton and Johnston, 2010). The retention of contaminants in the sediments, their bioavailability, and their potential toxicity are all strongly influenced by environmental factors, such as grain size distribution, salinity, $\mathrm{pH}$, redox potential, and levels of organic matter. In addition, these environmental factors are influenced by winds, tides, freshwater input, bioturbation, and other aspects that characterize natural estuarine dynamics (Chapman and Wang, 2001; Pekey, 2006; Idris, 2008).

Because sediments tend to integrate environmental variations over time, they can be used as an appropriate environmental compartment in environmental assessments. Many studies on sediment quality have been conducted and have provided information on the effects of sediment contaminants on aquatic organisms and ecosystems (Araújo et al., 2009; Cesar et al., 2009; Ré et al., 2009; Langston et al., 2010; Du et al., 2012; Gonçalves et al., 2013; Roig et al., 2015). In Brazil, investigations into sediment quality have been concentrated in some industrial and port zones of the southern and southeastern regions (Carvalho et al., 2002; Machado et al., 2002; Abessa et al., 2005; Pusceddu et al., 2007; Torres et al., 2009; Choueri et al., 2009a; Buruaem et al., 2013a; Fonseca et al., 2013; Rodrigues et al., 2013; Zalmon et al., 2013). On the other hand, studies conducted on the northeastern region of the country are still scarce (Buruaem et al., 2013b; Nilin et al., 2013; Krull et al., 2014), despite the ecological importance of this region to the biodiversity of the South Atlantic. The semi-arid coast is located in the northeastern region of Brazil, between the states of Piauí (PI) and Rio Grande do Norte (RN). It includes the Jundiaí-Potengi Estuary (JPE), which is the largest and most important in RN state. In spite of its socioeconomic and ecological importance, this estuary has been exposed to a variety of anthropic pressures, which include the discharge of untreated industrial and domestic effluents (Souza and Silva, 2011), runoff from agricultural areas, and discharges from shrimp farm effluents. Little is known about the sediment quality of this estuary (Buruaem et al., 2013b). The objective of this investigation was to consider both the dry and rainy seasons in order to assess the sediment quality of an estuary from the semi-arid coast of northeastern Brazil (JPE), which is influenced by multiple sources of contamination. To achieve this objective, different lines of evidence (LOEs), including geochemical and ecotoxicological analyses, were employed.

\section{Materials and methods}

\subsection{Study area}

The JPE is located on the eastern sector of the RN coast in northeastern Brazil, between the $5^{\circ} 53^{\prime} \mathrm{S}$ and $5^{\circ} 43^{\prime} \mathrm{S}$ latitudes and $35^{\circ} 21^{\prime} \mathrm{W}$ and $35^{\circ} 09^{\prime} \mathrm{W}$ longitudes (Fig. 1) (Souza and Silva, 2011). The estuary presents a maximum depth of $15 \mathrm{~m}$ and typical marine influence, in which the tidal fluxes range from 5000 to $20,000 \mathrm{~m}^{3} \cdot \mathrm{s}^{-1}$ (Silva et al., 2001; Boski et al., 2015). Freshwater input comes from the Potengi, Jundiaí and Doce Rivers; the Potengi River is the main contributor to the estuary, draining a basin with $3180 \mathrm{~km}^{2}$ and flow of $5 \mathrm{~m}^{3} \cdot \mathrm{s}^{-1}$ during the rainy period. The Jundiaí River has an intermediate flow but is more heavily influenced by tides. The Doce River presents the smallest freshwater contribution; its mean flow remains at about $2 \mathrm{~m}^{3} \cdot \mathrm{s}^{-1}$ for most of the year (Silva et al., 2006).

The climate in the region is characterized as tropical and semi-arid, with a dry season (September to February) that has a mean rainfall rate of $220 \mathrm{~mm}$, and with a rainy period (March to August) during which the mean rainfall rate is $1390 \mathrm{~mm}$. The annual mean precipitation rates range from 1300 to $2000 \mathrm{~mm}$ (Silva et al., 2007; Boski et al., 2015).

The JPE is approximately $30 \mathrm{~km}$ long, and its basin includes the cities of Macaíba, São Gonçalo do Amarante, and Natal, which have a combined population of more than 1.4 million people (IBGE, 2014). Approximately $60 \%$ of the raw sewage from Natal is discharged directly into the JPE; in addition, the estuary receives effluents from several industrial sources, such as textile factories, food and beverage producers, pulp mills, and leather and tannery manufacturers (Silva et al., 2006; SEPLAN, 2013). The estuary also receives effluents from shrimp farms and from the dumping sites where residues from urban septic tanks are stored and treated (IDEMA, 2008).

\subsection{Sediment sampling}

Two sampling surveys were conducted from which 10 sampling sites distributed along the JPE were considered (Fig. 1). The first survey occurred in May 2013 (the rainy season); the accumulated rainfall in that month was $399.1 \mathrm{~mm}$. The second survey was performed in December 2013 (the dry season). The rate of precipitation for that month was $9.8 \mathrm{~mm}$, and the accumulated precipitation for 2013 was $1846.7 \mathrm{~mm}$, according to EMPARN (2013). Sediments from the Galinhos Estuary ( $150 \mathrm{~km}$ northwest of the JPE) were collected to be used as reference sediments; this estuary is not impacted.

The sediment collection followed the recommendations described by Burton (1992). Composite sediment samples were collected from each site (with at least 3 subsamples) through the use of a stainless steel Van Veen grab sampler. From the material retained in the sampler, only the first $5 \mathrm{~cm}$ of the surface layer was separated. The sediments were transferred to plastic trays, thoroughly homogenized, and split into aliquots. The aliquots to be used for toxicity tests were conditioned in polyethylene flasks and stored at $4{ }^{\circ} \mathrm{C}$ in the dark until the assays were performed. The aliquots for the metal, organic carbon, and grain size distribution analyses were kept in polyethylene flasks and stored at $-20{ }^{\circ} \mathrm{C}$

\subsection{Geochemical analyses}

The sediment samples were dried at $45^{\circ} \mathrm{C}$ for 5 days, and aliquots were then separated for the following analyses: grain size distribution, organic matter (OM) contents, concentrations of total nitrogen $(\mathrm{N})$ and phosphorus (P) and metal concentrations ( $\mathrm{Fe}, \mathrm{Mn}, \mathrm{Cd}, \mathrm{Cr}, \mathrm{Cu}$, $\mathrm{Pb}, \mathrm{Ni}$, and $\mathrm{Zn}$ ). $100 \mathrm{~g}$ sediments were used to assess grain size distribution, in which quantities of mud $(<0.063 \mathrm{~mm})$ and sand $(>0.063 \mathrm{~mm})$ were determined (ABNT, 1988). OM levels were measured using the volumetric method described by EMBRAPA (1998), which is an adaptation of the Walkley-Black (1965) method. Concentrations of $\mathrm{N}$ and $\mathrm{P}$ were measured using the colorimetric method (Grasshoff et al., 1999).

For the chemical analysis, $5 \mathrm{~g}$ of the fine fractions $(<0.063 \mathrm{~mm})$ from the sediments were dried and digested using a mixture of $\mathrm{HCl} 0.05 \mathrm{M}$ and $\mathrm{H}_{2} \mathrm{SO}_{4} 0.0125 \mathrm{M}$ (EMBRAPA, 1998). The extracts were analyzed via atomic absorption spectrophotometry (model: Varian Spectr-AAS220-FS). The spectrophotometer was calibrated based on the reading the absorbance of six standards prepared for each element. The analytical precisions were established by analyzing a certified sediment (NIST 1646-A); the recoveries ranged from 80.7 to $114 \%$ (see supplementary material), values which are considered acceptable, and their uncertainties were below the acceptable limits (between $7 \%$ and $18 \%$ ). Metal concentrations in the JPE sediments were compared to those obtained at the reference site, and a risk quotient (RQ) was established based on the ratios between these concentrations (Roig et al., 2015). This quotient aims to evaluate both the pollution load and the potential risk to the biota as a result of the contribution of the eight elements measured, by defining four risk categories: low risk $(\mathrm{RQ}<1)$, moderate 


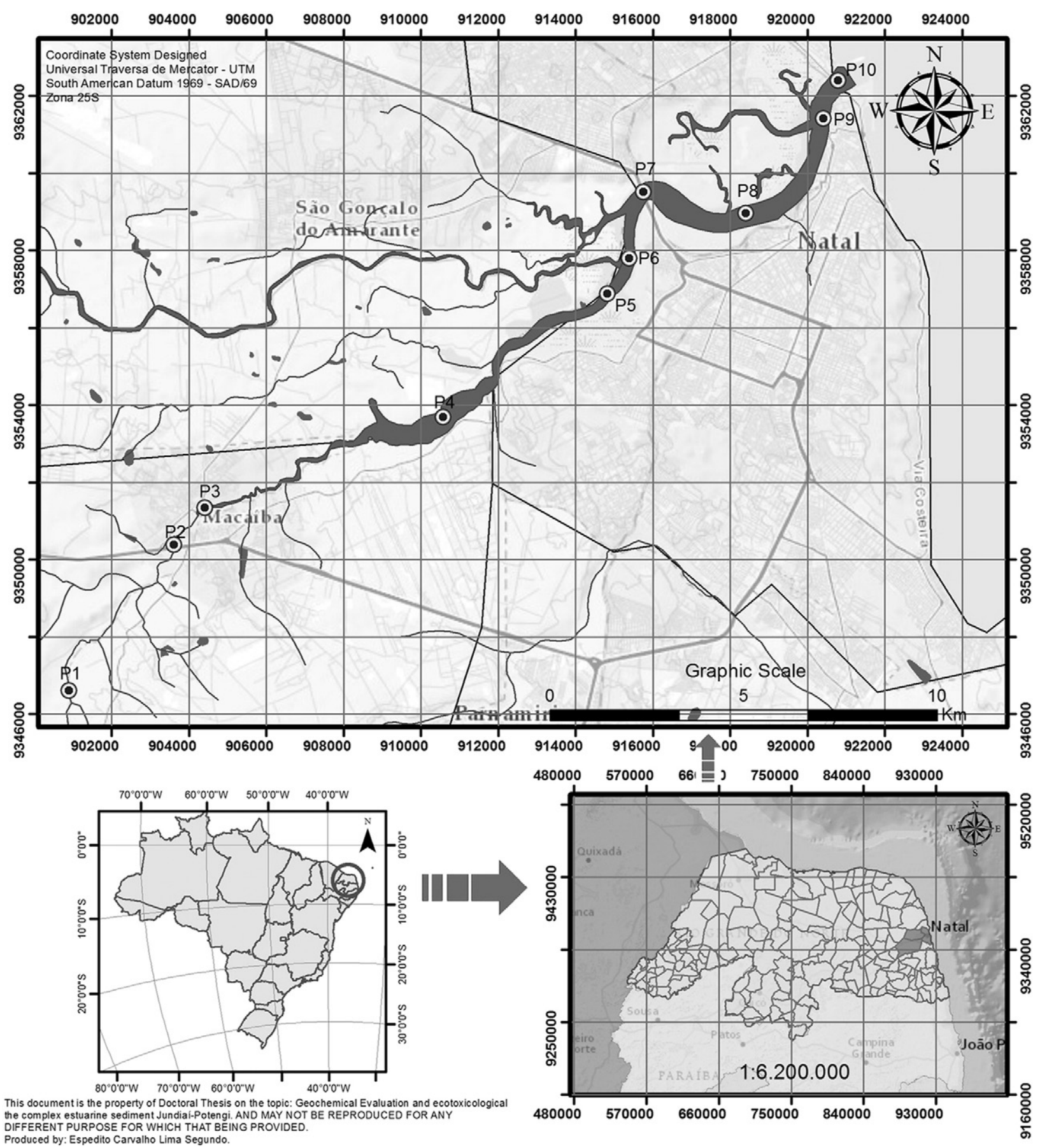

Fig. 1. Map of the study area and position of the sampling sites.

risk $(1 \leq \mathrm{RQ}<3)$, considerable risk $(3 \leq \mathrm{RQ}<6)$, and very high risk $(\mathrm{RQ} \geq 6$ ) (Loska et al., 1997; Islam et al., 2015).

Due to the considerable anthropic interferences in the study area, the evaluation of sediment contamination was made using the percentage enrichment factor (\%EF) defined by Zonta et al. (1994) and further used by Loska and Wiechuła (2003). The percentage enrichment factors (EFs) were calculated according to the following equation:

$\mathrm{EF}(\%)=[(\mathrm{C}-\mathrm{Cmin}) /(\mathrm{Cmax}-\mathrm{Cmin})] \times 100$

where $\mathrm{C}$ indicates the mean concentration of the concerned element, $\mathrm{Cmin}$ and $\mathrm{Cmax}$ indicate the respective minimum and maximum concentrations determined during the period of investigation. To evaluate the metal load at each site, the EFs of all of the elements were added together, as suggested by Adamo et al. (2005).

\subsection{Sediment toxicity}

Sediments were tested for acute toxicity (AT) and chronic toxicity (CT), in which organism exposure to whole-sediment (WS) and sediment-water interface (SWI) was considered. For all toxicity tests, physical and chemical parameters - which included pH, salinity, dissolved oxygen (DO), and temperature - were determined at the beginning and end of each experiment. The original tables containing this information can be seen in the supplementary material. 


\subsubsection{Whole-sediment acute toxicity}

The whole-sediment acute toxicity tests were conducted using the amphipods Leptocheirus plumulosus and Tiburonella viscana and following the protocols described by ABNT (2008) and Melo and Abessa (2002), respectively. T. viscana specimens were collected from the Engenho D'água Beach (Ilhabela, São Paulo, Brazil) and were then acclimated to laboratory conditions over 3 days. Sediment from this beach was collected to be used as internal control. L. plumulosus specimens were obtained from a culture maintained in laboratory.

The tests consisted of exposing the amphipods (20 juvenile L. plumulosus specimens and 10 adult $T$. viscana specimens per replicate) to the sediments for a 10-day period. Test chambers consisted of polyethylene flasks containing approximately $200 \mathrm{ml}$ of homogenized sediment and filtered sweater (salinities of $20 \%$ for L. plumulosus and $34 \%$ for $T$. viscana). The system was kept under constant lighting and aeration and at a temperature of $25 \pm 2{ }^{\circ} \mathrm{C}$. At the end of the test, the contents of each test chamber were sieved, and the surviving organisms were counted. Missing organisms were considered dead. Three replicates were used for each sample.

\subsubsection{Whole-sediment chronic toxicity}

The copepod Nitocra sp. was used as the test organism for the wholesediment chronic toxicity tests, based on the protocol developed by Lotufo and Abessa (2002). The copepods were obtained from a culture kept in the laboratory. Four replicates were set up for each sample, and $15 \mathrm{ml}$ of high density polyethylene test chambers filled with $2 \mathrm{ml}$ of sediment and $8 \mathrm{ml}$ of filtered sea water (salinity 17\% ) were used. Ten healthy ovigerous females were introduced into each replicate. The entire test system was incubated at $25 \pm 2{ }^{\circ} \mathrm{C}$ with a $12 \mathrm{~h}: 12 \mathrm{~h}$ (light:dark) photoperiod for 10 days. Next, the content of each replicate was fixed with formaldehyde (10\%) and Rose-Bengal dye (0.1\%). Finally, the adult females and their offspring (nauplii and copepodits) were counted using a stereomicroscope.

\subsubsection{Chronic toxicity of the sediment-water interface}

The sediment-water interface chronic toxicity test was conducted following the method described by Anderson et al. (2001) and adapted by Cesar et al. (2004) for small volumes. This treatment assesses the effects of contamination that arises from sediment and which may affect organisms in the adjacent water column. In this procedure, the test system was set up in test tubes containing sediment and water 1:4 (v:v).The samples were then tested for toxicity by analyzing the embryo-larval development of the sea urchin Lytechinus variegatus according to ABNT NBR protocol No. 15350 (ABNT, 2012). Sea urchin spawning was induced and subsequent in vitro fertilization was implemented. The test was conducted by introducing approximately 400 embryos in each of the four replicates, as well as in a negative control (filtered seawater). After the test ( $24 \mathrm{~h}$ ), embryos were analyzed microscopically for morphological abnormalities and delayed development.

\subsection{Interpretation and integration of the ecotoxicological data}

The results of all toxicity data were checked for normal distribution using the Chi-Square test. Variance homogeneity was assessed using
Fisher's exact test. Student's t-test was then used to compare each sample to its respective control. Sediments were considered significantly toxic when the value for the respective endpoint (mortality, fecundity, embryo development) was lower than the value observed in the control (e.g. when $\mathrm{p} \leq 0.05$ ). The analyses were run using the STATISTICA 7 software tool.

The results of all of the tests were then combined, and the qualitative conclusions of each test were considered. The criteria for classifying the sediments based on their toxicities are shown in Table 1. For the amphipod tests, non-toxic sediments were considered good, and the significantly toxic sediments were classified as poor $(<50 \%$ difference from the control) or very poor ( $\geq 50 \%$ in common with the control). A similar criterion was used in the copepod test. Meanwhile, for the sea-urchin embryo test, there were four classes (good: not toxic; moderate: development inhibition rates ranging from 30 to $49 \%$; poor: development inhibition rates between $50 \%$ and $74 \%$; very poor: development inhibition equal or greater than $75 \%$ ). Finally, to determine the sediment quality at each site based on the combination of toxicity tests, the results regarding acute and chronic toxicity were combined in order to produce five possible sediment quality classes (Fig. 2). Because acute toxicity generally indicates severe responses, our approach was conservative and gave more weight to the results of acute toxicity.

\subsection{Integration of geochemical and ecotoxicological data}

Geochemical and toxicity data were integrated using cluster analyses (CAs), with the Euclidean distance and the Ward's method, and also using factor analysis with data extracted with the principal component analysis (FA-PCA). The data matrix used for these analyses was comprised of the results on OM, muds, Nitrogen, Phosphorus, and metals ( $\mathrm{Fe}, \mathrm{Mn}, \mathrm{Cd}, \mathrm{Cr}, \mathrm{Cu}, \mathrm{Pb}, \mathrm{Ni}, \mathrm{Zn}$ ) concentrations, amphipod mortality, reduction in copepod fecundity, and the abnormal development rate of sea-urchin embryos. In the FA-PCA, we used 0.4 as the cut-off value (Comrey and Lee, 1992), which is equal to or higher that the criteria used by Choueri et al. (2009a, 2009b, 2010) and Rodrigues et al. (2013). The selection of the number of principal components was based on the Scree plot method, and the analysis considered the normalized Varimax rotation. Prior to both the CAs and the FA-PCA, the data was auto-scaled in order to reduce the magnitude differences between variables.

\subsection{Quality assurance/quality control (QA/QC)}

The QA/QC procedures included the use of replicates and repeatability tests in the analyses of total $\mathrm{N}$ and $\mathrm{P}$, as well as the use of analytical blanks and standard reagents. In the case of metals, the calibration curve was adjusted using linear regression, and the curves obtained for each element showed the relationships between the absorbances and the concentrations of the known solutions. Method validation included the analysis of a standard sediment (NIST 1646-A). The analytical precisions were within the acceptable limits for uncertainty and ranged from $7 \%$ to $18 \%$. In the ecotoxicological tests, the experimental variables ( $\mathrm{pH}, \mathrm{DO}$, temperature, salinity, and luminosity) were monitored. Tests with reference substances were run for each species or

Table 1

Criterion for classifying the sediment quality in the Jundiaí-Potengi Estuary based on the toxicity to marine/estuarine invertebrates.

\begin{tabular}{|c|c|c|c|c|c|c|}
\hline \multirow[t]{2}{*}{ Test type } & \multirow[t]{2}{*}{ Endpoint } & \multirow[t]{2}{*}{ Species } & \multicolumn{4}{|c|}{ Sediment classification for toxicity } \\
\hline & & & Good & Moderate & Poor & Very poor \\
\hline Acute & $\%$ mortality & $\begin{array}{l}\text { L. plumulosus } \\
\text { T. viscana }\end{array}$ & NT & - & $<50 \%^{\mathrm{a}}$ & $\geq 50 \%$ \\
\hline Chronic & $\begin{array}{l}\text { fecundity ((nauplii }+ \text { copepodits)/female) } \\
\% \text { abnormal development }\end{array}$ & $\begin{array}{l}\text { Nitocra sp. } \\
\text { L. variegatus }\end{array}$ & $\begin{array}{l}\text { NT } \\
\text { NT }\end{array}$ & $-\overline{30-49 \%}$ & $\begin{array}{l}<50 \%{ }^{\mathrm{b}} \\
50-74 \%\end{array}$ & $\begin{array}{l}\geq 50 \% \\
>75 \%\end{array}$ \\
\hline
\end{tabular}

NT: not significantly toxic in relation to the controls.

a Mortality below 50\%, but significantly different from the reference sediment.

b Significantly toxic (in comparison with the controls) but the difference from the control group is less than $50 \%$. 


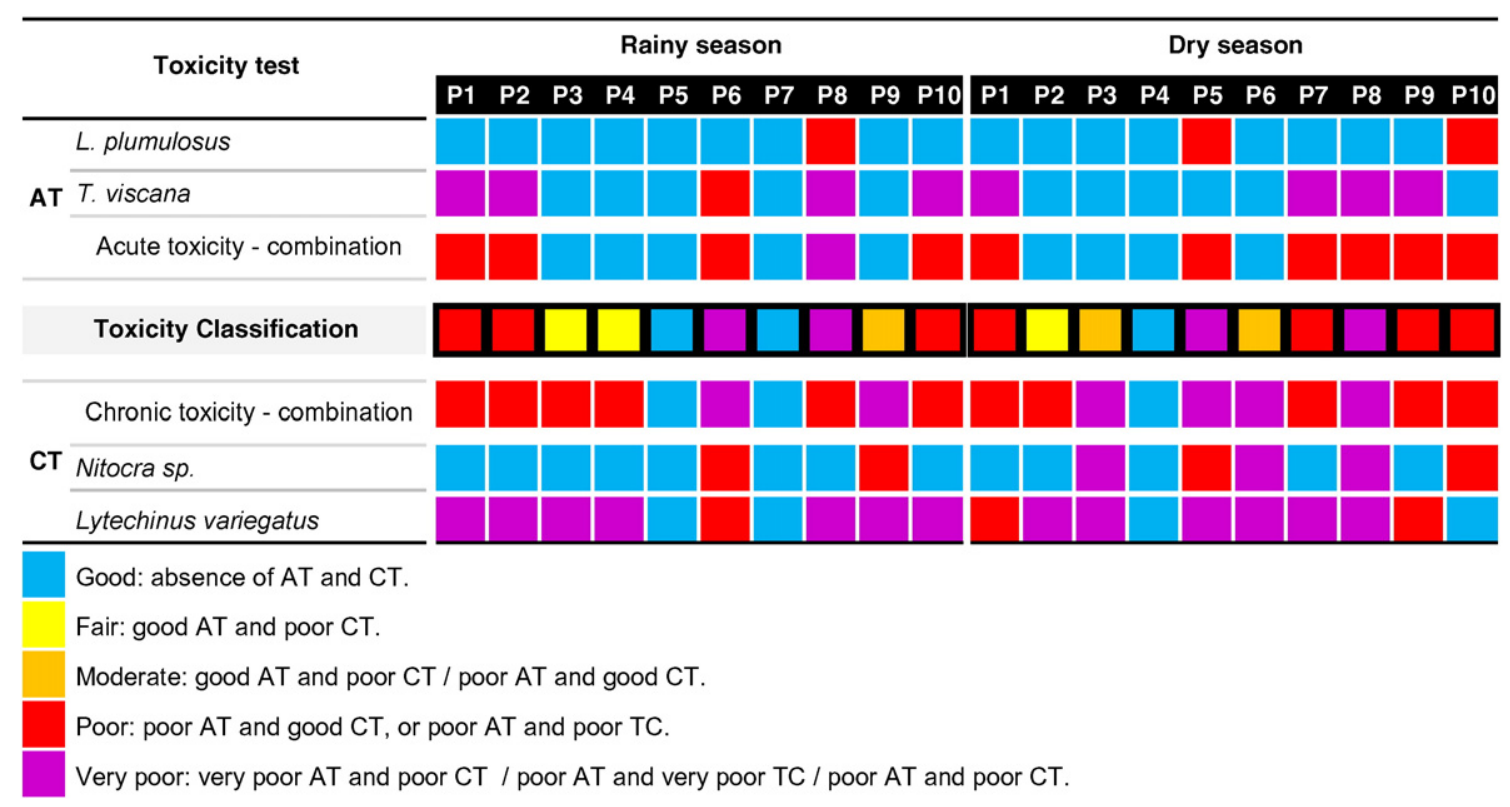

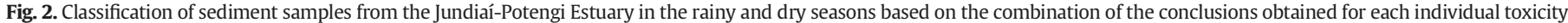
test (amphipod mortalities, inhibition of copepod reproduction, and reduction in normal sea urchin embryo development).

survey in order to evaluate the sensitivity of the test organisms. Tests were used to determine L. plumulosus and T. viscana sensitivities to zinc sulfate and potassium dichromate, respectively. The LC50-48 h for T. viscana was estimated to be $8.2 \mathrm{mg} \cdot \mathrm{L}^{-1}\left(6.25-9.37 \mathrm{mg} \cdot \mathrm{L}^{-1}\right.$ $\mathrm{K}_{2} \mathrm{Cr}_{2} \mathrm{O}_{7}$ ), while the LC50-96 h for L. plumulosus was estimated to be $0.89 \mathrm{mg} \cdot \mathrm{L}^{-1}\left(0.67-17 \mathrm{mg} \cdot \mathrm{L}^{-1}\right)$. Both values were within the acceptable ranges defined by the respective control charts. Nitocra sp. sensitivity to $\mathrm{K}_{2} \mathrm{Cr}_{2} \mathrm{O}_{7}$ was determined as well, and the $\mathrm{LC} 50-96 \mathrm{~h}$ was estimated to be $26.92 \mathrm{mg} \cdot \mathrm{L}^{-1}\left(16.25-33.33 \mathrm{mg} \cdot \mathrm{L}^{-1}\right.$, which is within the acceptable range. Finally, L. variegatus sensitivity to zinc sulfate was estimated, and EC50-24 h values ranged from 0.20 to $0.43 \mathrm{mg} \cdot \mathrm{L}^{-1}$, values which were within the range established in the control chart.

\section{Results and discussion}

\subsection{Sediment properties}

The results of the geochemical characterization of the sediment samples are summarized in Table 2. The sediment textures along the estuary were heterogeneous overall, particularly in the second survey (dry season). Fine sediments were predominant in the mid-estuary (P4-P7) and in the lower estuary (P8-P10). This high percentage of mud is an indication of the low hydrodynamic energy in these portions of the JPE, as is the presence of a dense mangrove forest, which increases fine particle retention. In addition, the narrow mouth of the JPE may contribute to the siltation process within the estuary.

The quantities of OM in the sediments ranged from 0.05 to $12.67 \%$. The highest values were observed during the dry season, possibly finding which may be due to the lower turbulence and higher deposition rate during this period. In both sampling campaigns, the highest levels of OM occurred in the mid-estuary (P4-P7). However, all along the JPE, OM levels were within the range expected for tropical estuaries from northeastern Brazil (0.76-38.9\%) (Freire et al., 2004; Lacerda and Marins, 2005; Marques et al., 2008; Nascimento et al., 2010). The distribution of OM in the sediments presented a pattern similar to that exhibited by the fine sediments, a finding which reinforces the possibility that the lower and mid-estuarine zones are depositional areas. Moreover, in these portions of the JPE, both human activity and natural sources may be contributing to the increase in OM levels. OM input to the JPE is influenced by the seasonal population increase resulting from tourism, especially during the dry season. In addition, effluents and residues from the shrimp farms are continuously released into the JPE. There are 61 shrimp farms in the vicinity of the JPE basin; they cover approximately 1440 ha (Medeiros, 2009), and are most frequent along the banks of the mid- and lower-estuary.

\subsection{Nutrients (total nitrogen and phosphorus)}

Phosphorus concentrations were highest in the internal portion of the estuary, and they decreased progressively as the sites became closer to the mouth of the JPE. The P2 and P6 sites presented the highest concentrations in both seasons. In general, the concentrations were higher during the rainy season. When nitrogen levels were assessed, there was no clear pattern for the element's distribution in the sediments in either season, but the concentrations tended to be higher during the rainy season. In the dry season, sediments from the mid-estuary (P4 and P6) and from the lower estuary (P8-P10) presented the highest concentrations, particularly those from P8 $\left(2580 \mathrm{mg} \cdot \mathrm{kg}^{-1}\right)$. P8 is close to the mouth of the Baldo Channel, which carries a large amount of untreated sewage and other domestic residues into the JPE (Silva et al., 2001).

The relatively high levels of nitrogen and phosphorus in the sediments from P2 and P7, particularly in the first campaign, may be a result of leakage from agricultural areas or urban drainage during rainstorms. According to Singh et al. (1997) and Walker et al. (1999), urban drainage contributes to pollution loads in estuaries that cross urban areas. Nitrogen and phosphorus are important nutrients for organisms, but they can be introduced into coastal environments through sewage and urban effluents (Mackenzie and Chou, 1993), and high values can cause eutrophication. Tavares et al. (2014) observed the phenomenon of eutrophication in the JPE, which was dependent on tidal conditions and rainfall precipitation levels. Shrimp farms also represent important sources of nitrogen and phosphorus for the JPE; large amounts of fertilizer and shrimp food are employed to accelerate shrimp growth (Lacerda et al., 2006a; Silva et al., 2010; Marins et al., 2011). Thus, we can infer that there are multiple sources of $\mathrm{N}$ and $\mathrm{P}$ contributing to the JPE. 
Table 2

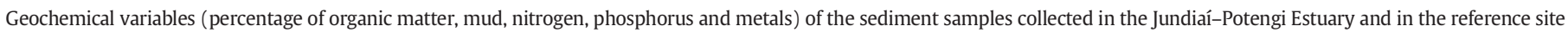
(Galinhos Estuary) during the rainy and dry seasons.

\begin{tabular}{|c|c|c|c|c|c|c|c|c|c|c|c|c|}
\hline \multirow[t]{3}{*}{ Sampling Sites } & \multicolumn{12}{|c|}{ Geochemical analyses } \\
\hline & $\mathrm{N}$ & $\mathrm{P}$ & Mn & $\mathrm{Cr}$ & $\mathrm{Cu}$ & $\mathrm{Cd}$ & $\mathrm{Ni}$ & $\mathrm{Pb}$ & $\mathrm{Zn}$ & $\mathrm{Fe}$ & $\mathrm{OM}$ & Mud \\
\hline & \multicolumn{9}{|c|}{$\left(\mathrm{mg} \cdot \mathrm{kg}^{-1}\right)$} & \multicolumn{3}{|l|}{ (\%) } \\
\hline \multicolumn{13}{|l|}{ Rainy season } \\
\hline P1 & 340 & 17 & 21.74 & $<0.01$ & 0.90 & 0.02 & 0.86 & 1.29 & 2.47 & 0.569 & 0.59 & 12.7 \\
\hline P2 & 1340 & 175 & 9.26 & $<0.01$ & 7.46 & 0.15 & 3.58 & 6.51 & 30.17 & 0.598 & 3.15 & 23.6 \\
\hline P3 & 1120 & 85 & 9.65 & $<0.01$ & 3.81 & 0.12 & 2.31 & 3.05 & 6.30 & 0.443 & 4.43 & 32.2 \\
\hline P4 & 280 & 136 & 23.39 & 0.27 & 3.08 & 0.19 & 2.21 & 3.30 & 11.36 & 0.611 & 5.53 & 36.7 \\
\hline P5 & 1680 & 113 & 15.00 & 0.74 & 2.42 & 0.25 & 2.82 & 2.87 & 10.41 & 0.392 & 6.22 & 39.5 \\
\hline P6 & 900 & 117 & 52.62 & 0.37 & 2.72 & 0.22 & 1.83 & 2.44 & 8.68 & 0.494 & 4.57 & 34.7 \\
\hline P7 & 1230 & 29 & 22.57 & 0.51 & 1.82 & 0.37 & 2.18 & 3.12 & 13.23 & 0.281 & 5.04 & 34.6 \\
\hline P8 & 950 & 2 & 8.16 & 0.64 & 6.63 & 0.26 & 1.29 & 4.74 & 26.22 & 0.471 & 3.12 & 17.9 \\
\hline P9 & 1060 & 1 & 22.96 & $<0.01$ & 0.41 & 0.36 & 1.22 & 2.24 & 1.82 & 0.011 & 4.55 & 31.7 \\
\hline P10 & 780 & 1 & 18.36 & $<0.01$ & 0.40 & 0.33 & 0.98 & 2.17 & 1.27 & 0.005 & 1.78 & 39.8 \\
\hline GAL & 220 & 2 & 11.23 & $<0.01$ & 0.48 & 0.25 & 1.11 & 1.24 & 1.45 & 0.007 & 3.72 & 30.4 \\
\hline \multicolumn{13}{|l|}{ Dry season } \\
\hline P1 & 340 & 9 & 78.50 & $<0.01$ & 1.63 & $<0.01$ & 1.76 & 1.05 & 2.53 & 0.579 & 0.35 & 17.6 \\
\hline P2 & 220 & 17 & 21.11 & $<0.01$ & 0.29 & $<0.01$ & 0.38 & 0.25 & 2.13 & 0.437 & 0.05 & 3.5 \\
\hline P3 & 170 & 47 & 10.35 & 0.26 & 17.90 & 0.08 & 1.56 & 1.85 & 4.96 & 0.253 & 2.18 & 18.9 \\
\hline P4 & 1960 & 141 & 98.60 & 0.93 & 2.46 & 0.38 & 4.14 & 3.92 & 14.46 & 0.655 & 11.38 & 67.8 \\
\hline P5 & 170 & 94 & 46.62 & 0.94 & 0.64 & 0.47 & 3.10 & 2.70 & 10.61 & 0.336 & 12.67 & 61.0 \\
\hline P6 & 1570 & 34 & 34.03 & 0.70 & 1.64 & 0.29 & 1.92 & 2.18 & 8.84 & 0.456 & 8.58 & 45.6 \\
\hline P7 & 390 & 1 & 21.32 & 0.39 & 0.40 & 0.35 & 1.24 & 1.96 & 3.67 & 0.054 & 4.04 & 40.5 \\
\hline P8 & 2580 & 1 & 29.33 & 0.53 & 0.65 & 0.49 & 1.51 & 2.45 & 2.21 & 0.005 & 6.39 & 69.9 \\
\hline P9 & 1010 & 2 & 15.48 & 0.42 & 0.42 & 0.36 & 1.06 & 2.02 & 1.61 & 0.010 & 4.98 & 58.4 \\
\hline P10 & 1120 & 1 & 20.90 & 0.41 & 0.43 & 0.35 & 1.07 & 1.79 & 1.25 & 0.005 & 3.04 & 46.3 \\
\hline GAL & 140 & 2 & 12.55 & 0.42 & 0.46 & 0.25 & 1.11 & 1.06 & 1.19 & 0.008 & 3.46 & 31.1 \\
\hline
\end{tabular}

GAL: Reference site - Galinhos Estuary northeastern Brazil.

Previous studies (Souza and Silva, 2011) showed that the region between the cities of Natal and São Gonçalo do Amarante (close to P8, P9 and P10) corresponds to a portion of the estuary that has been increasingly degraded over the last few decades. According to theses authors, the main causes of degradation include urban expansion, the release of raw sewage, and the replacement of mangrove forests with shrimp farms and with anaerobic ponds from sewage effluent plants; these sources explain the high levels of nitrogen that were found in the lower JPE in the current study.

\subsection{Metals}

Most of the metal concentrations found in the sediments were higher in the rainy season, with the exception of $\mathrm{Mn}, \mathrm{Cd}$, and $\mathrm{Cr}$ (see Table 2). During the rainy season, the higher concentrations tended to occur in sediments from P2-P8 (sites which represent almost the entire length of the estuary). Meanwhile, in the dry season, the highest levels of metals were observed in the sediments from P4-P6. The difference in levels between dry and rainy seasons suggests an influence of the drainage from urban and agricultural areas on the distribution of metals along the JPE. Rainstorms in tropical areas are considered important for sustaining river flows and contribute to contaminant runoff from the surrounding areas (Nilin et al., 2013). Ambrozevicius and Abessa (2008) observed that storm water runoff and urban drainage have contributed to the degradation of water quality in some urban channels located in the Santos Bay (southeast Brazil).

However, the long dry season on the semi-arid coast causes the rivers to be perennial only in their estuarine portions, since the freshwater input drops to minimum levels. Thus, the reduced river flow is not strong enough to reach the sea and remains blocked within the estuarine zone by the marine waters (Lacerda et al., 2012), thus increasing the water's residence time in this region. Under these conditions, contaminants tend to be retained within the estuary during the dry season, and only a small fraction is carried to the sea as dissolved metals. This phenomenon can explain the higher concentrations of metals in the intermediate portions of the JPE, especially in the sediments collected between P4 and P6 (Table 4). On the other hand, the exportation of contaminants toward the sea tends to occur predominantly during the rainy season, when the flow becomes strong enough to break the resistance imposed by marine waters (Lacerda et al., 2007, 2012). This explains, at least partially, the larger number of sampling sites affected by metal contamination. For this reason, it can be inferred that the presence of multiple contamination sources along the entire JPE do not support the idea of metal retention in the sediments from the sites located upstream.

Many studies have reported that the physical and chemical properties of surface waters also can regulate metal precipitation or solubilization and thus influence the mechanisms involved in the temporal geochemical variability of coastal sediments (Cooper and Morse, 1998; Warnken et al., 2001). Lau (2000) concluded that salinity and temperature variations influenced the dynamics of metals through the sediment-water interface in a subtropical estuary, thus increasing metal availability to the biota. There is a consensus that other factors, such as the redox potential and $\mathrm{pH}$, may influence metal precipitation and mobilization in coastal sediments, since they alter the stability of some compounds involved in the contaminant retention process in sediments (Chapman and Wang, 2001), as is the case of sulfides (Otero and Macias, 2002). However, these factors cannot be considered the only factors responsible for the changing behavior of metal concentrations in sediments. Human activity must also be considered, since multiple point and diffuse sources are present along the JPE, and their contributions of metals vary over time, as observed by Guedes (2012). Marins et al. (2004) found a similar situation in other estuaries from northeastern Brazil.

Metal concentrations in sediments from the JPE were lower than global geological reference levels (Turekian and Wedepohl, 1961) and were also lower than those adopted by the Brazilian government as standards for sediment dredging and disposal (CONAMA, 2012); these 
results are consistent with those obtained by Dantas (2009). The concentrations were comparable to levels found in other estuaries of Brazil and lower than those observed around the world (Table 3). Possible reasons for relatively lower levels of nutrients and metals in JPE in comparison to other sites worldwide may include the fact that our study the metals were extracted by weak acid digestion; and the regional concentrations of these elements are low, as suggested by the results for the reference site and by previous studies in JPE (Sindern et al., 2007; Buruaem et al., 2013b). International sediment quality guidelines must be used with caution, since they may not represent the best basis for comparison (Marins et al., 2004). Abessa et al. (2008) observed that more than $75 \%$ of the sediments from the Santos Estuarine System that exhibited concentrations above the Canadian threshold effect levels (TELs) were toxic to marine invertebrates, and these authors stated that the sediment quality guidelines (SQGs) for tropical regions may need to be lower than those of temperate zones. Choueri et al. (2009b) and Buruaem et al. (2012) showed that site-specific SQGs could be much more reliable for predicting toxicity than those adopted by the Brazilian legislation. Thus, we adopted risk quotients (Loska et al., 1997; Islam et al., 2015) and enrichment factors (Zonta et al., 1994) to evaluate the geochemical conditions of the JPE.

Risk quotient (RQ) and enrichment factor (EF) values are shown in Table 4. Total EF values ranged from 16.9 to $67.2 \%$ during the rainy season and were between 10.6 and $97.1 \%$ during the dry season. The most enriched sediments (\%EF > 50) during the rainy season were P2 $>$ P8 $>$ P5 $>$ P6, while in the dry season, the most enriched samples were those from P4 $>$ P5 $>$ P6. The RQ values indicated that the sediments from sites P2-P8 were of considerable or very high risk during the rainy season, and that those from P4-P6 were of considerable risk $(R Q \geq 3)$ during the dry season. Results obtained for \%EF and RQ were in agreement and presented similar metal accumulation patterns. The enrichment of metals in the sediments was clearly demonstrated, a result which indicates the influence of human activity, particularly in the mid-estuary, where sediments were found to be of considerable or very high risk. The mid-estuary also coincides with the regions where deposition and accumulation of organic matter, fine particles, and nutrients would be expected due to the hydrological regime.

Many sources of pollution are established along the JPE, particularly near the mid-estuary. These include 26 factories representing different sectors (textile, food and beverages, pulp, and leather and tannery), and most of them discharge their effluents along the intermediate estuarine zone (IDEMA, 2008; Souza and Silva, 2011). The contribution of effluents from the textile factories is the most relevant source of pollution. Alencar et al. (2005) and Vandevivere et al. (1998) reported that their composition includes organic compounds (such as detergents), carbonates, sulfates and chlorides, and also metals $(\mathrm{Zn}, \mathrm{Ni}, \mathrm{Cr}, \mathrm{Cd}, \mathrm{Pb}$, and Fe), among other substances. These effluents may be associated with enrichment of metals in the JPE sediments, particularly in the region between P4 and P6.

Metal contamination may be linked to the surrounding shrimp farms as well. This activity occurs close to the mid-estuary and the low estuary (Silva et al., 2007; Souza and Silva, 2011), and it is associated with a series of contaminants, including copper-based fungicides and algaecides (Boyd and Massaut, 1999), as well as with shrimp feed, which presents high levels of $\mathrm{Cu}, \mathrm{Zn}$, and Mn (Lacerda et al., 2006b; Cunha, 2010).

Therefore, the enrichment of metals in sediments from the JPE may be a result of a combination of human activity and natural factors.

\subsection{Sediment toxicity}

Sediment toxicity tests have been widely used as a line of evidence (LOE) to evaluate the quality of sediments and the bioavailability of chemicals (Cesar et al., 2009). The combined use of different toxicity tests has been recommended by Abessa et al. (2008) in order to provide more reliable information on sediment quality. For this reason, we used 4 different species and considered both acute and chronic toxicities. As shown in Table 5, sediments from P1, P2, P6, P8, and P10 presented chronic and acute toxicities for at least one of the tested organisms. The sediments from P3, P4 and P9 were chronically toxic. In the dry season, sediments from P2, P3, and P6 presented only chronic toxicity. In both campaigns, there was not any sediment that showed only acute toxicity - as expected, more samples presented chronic toxicity than acute toxicity. This fact highlights that more weight should be placed upon acute toxicities when sediment quality is assessed.

The combination of the results from the chronic and acute toxicity tests showed that sediments from P6 and P8 (during the rainy season) and from P5 and P8 (during the dry season) were toxic to the point of negatively affecting amphipod survival, copepod reproduction, and the development of sea urchin embryos (Fig. 2). On the other hand, sediments from P5 and P7 (during the rainy season) and from P4 (during the dry season) were not toxic. These results showed that toxicities of sediments from the mid-estuary change over time, despite the higher levels of metals and nutrients in this portion of the JPE.

Sediments from the lower and upper portions of the JPE were toxic in both seasons. These findings corroborate the study conducted by Buruaem et al. (2013b), in which chronic toxicity was found along the length of the estuary, while acute effects were associated only with sediments from the inner portion of the estuary. Previous studies found metal bioaccumulation in bivalves, barnacles and crabs collected along the JPE (Silva et al., 2001, 2006; Lopes, 2012), and foraminiferal assemblages from the estuary exhibited signs of environmental stress.

Table 3

Concentrations of metals $\left(\mathrm{mg} \cdot \mathrm{kg}^{-1}\right)$ in sediments from different estuarine zones of the world (iron concentrations are expressed in \%).

\begin{tabular}{|c|c|c|c|c|c|c|c|c|}
\hline Region & $\mathrm{Fe}$ & $\mathrm{Mn}$ & $\mathrm{Cr}$ & $\mathrm{Cu}$ & $\mathrm{Cd}$ & $\mathrm{Ni}$ & $\mathrm{Pb}$ & $\mathrm{Zn}$ \\
\hline Jundiaí-Potengi Estuary (Brazil) $^{1 \mathrm{a}}$ & $0.005-0.61$ & $8.1-52.2$ & $<0.01-0.74$ & $0.4-7.4$ & $0.02-0.37$ & $0.8-3.5$ & $1.2-6.5$ & $1.2-30.1$ \\
\hline Jundiaí-Potengi Estuary (Brazil) $^{1 \mathrm{~b}}$ & $0.005-0.65$ & $10.3-98.6$ & $<0.01-0.94$ & $0.29-2.4$ & $<0.01-0.49$ & $0.3-4.14$ & $0.2-3.9$ & $1.1-14.4$ \\
\hline Potengi River (Brazil) $)^{2}$ & $0.47-0.6$ & - & $7.2-20.8$ & $1.6-3.7$ & $<0.01-0.013$ & $3.8-11.8$ & $1.67-4.67$ & $6.7-12$ \\
\hline Guaratuba Bay (Brazil) ${ }^{3}$ & - & - & - & $0.58-8.49$ & $0.07-0.40$ & - & $1.38-2.51$ & $0.39-2.14$ \\
\hline Paranaguá Estuarine System (Brazil) ${ }^{4}$ & - & - & $14,5-58$ & $<0.04-16.2$ & $<0.01$ & $6.6-21.9$ & $<0.3-29.7$ & $26.9-80$ \\
\hline Parnaíba River Delta (Brazil) $)^{5}$ & $0.3-2.5$ & $145-1356$ & $1.5-38$ & $1.5-48$ & - & - & $1.5-28$ & $2.6-31$ \\
\hline Tapacurá River (Brazil) ${ }^{6}$ & 0.7 & 53.8 & 1.7 & 12.5 & 0.3 & 1.1 & 0.2 & 18.9 \\
\hline Port of Rotterdam (Netherlands) ${ }^{7}$ & - & - & - & $<5-40$ & $0.5-1.8$ & $<5-20$ & $<10-60$ & $15-190$ \\
\hline Port of Cádiz (Spain) $)^{8}$ & - & - & $0.1-14.9$ & $7-202$ & $0.92-1.3$ & $0.06-21.3$ & $2.3-86.9$ & $21.27-378$ \\
\hline Daya Bay (China) ${ }^{9}$ & - & - & - & 20.8 & 0.05 & 31.2 & 45.7 & 113 \\
\hline River Ganges (India) ${ }^{10}$ & - & - & $1.8-6.4$ & $0.98-4.4$ & $0.14-1.4$ & - & $4.3-8.4$ & - \\
\hline Toxicity reference value $^{11}$ & - & - & 26 & 16 & 0.6 & 16 & 31 & - \\
\hline World average $\mathrm{e}^{12}$ & 4.7 & 850 & 90 & 45 & - & - & 20 & 95 \\
\hline
\end{tabular}

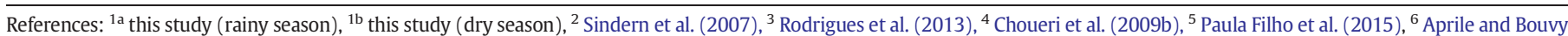
(2008), ${ }^{7}$ Van Den Hurk et al. (1997), ${ }^{8}$ Casado-Martínez et al. (2009), ${ }^{9}$ Gao and Chen (2012), ${ }^{10}$ Gupta et al. (2009), ${ }^{11}$ USEPA (1999), ${ }^{12}$ Turekian and Wedepohl (1961). 
Table 4

Enrichment factors for metals (\%EF) and risk quotients of toxicity (RQ) obtained for the sediments collected from the Jundiaí-Potengi Estuary in the rainy and dry seasons.

\begin{tabular}{|c|c|c|c|c|c|c|c|c|c|c|c|c|c|c|c|c|c|c|c|}
\hline \multirow[t]{2}{*}{ Seasons } & \multicolumn{8}{|c|}{ Enrichment Factor (\%EF) } & \multirow[t]{2}{*}{ EF-total } & \multicolumn{8}{|c|}{ Risk Quotient (RQ) } & \multirow[t]{2}{*}{ RQ-total } & \multirow{2}{*}{$\begin{array}{l}\text { Classification } \\
\text { RQ }\end{array}$} \\
\hline & $\mathrm{Fe}$ & $\mathrm{Mn}$ & $\mathrm{Cr}$ & $\mathrm{Cu}$ & $\mathrm{Cd}$ & $\mathrm{Ni}$ & $\mathrm{Pb}$ & $\mathrm{Zn}$ & & $\mathrm{Fe}$ & $\mathrm{Mn}$ & $\mathrm{Cr}$ & $\mathrm{Cu}$ & $\mathrm{Cd}$ & $\mathrm{Ni}$ & $\mathrm{Pb}$ & $\mathrm{Zn}$ & & \\
\hline \multicolumn{20}{|c|}{ Rainy season } \\
\hline $\mathrm{P} 1$ & 93 & 31 & 0 & 7 & 0 & 0 & 0 & 4 & 16.9 & 8.1 & 1.0 & 0 & 1.9 & 0.1 & 0.8 & 1.0 & 1.7 & 1.9 & Moderate \\
\hline P2 & 98 & 3 & 0 & 100 & 37 & 100 & 100 & 100 & 67.2 & 8.5 & 0.8 & 0 & 15.5 & 0.6 & 3.2 & 5.3 & 20.8 & 6.8 & Very high \\
\hline P3 & 72 & 3 & 0 & 48 & 29 & 53 & 34 & 17 & 32.1 & 6.3 & 0.9 & 0 & 7.9 & 0.5 & 2.1 & 2.5 & 4.3 & 3.1 & Considerable \\
\hline P4 & 100 & 34 & 36 & 38 & 49 & 50 & 39 & 35 & 47.5 & 8.7 & 2.1 & 0.3 & 6.4 & 0.8 & 2.0 & 2.7 & 7.8 & 3.8 & Considerable \\
\hline P5 & 64 & 15 & 100 & 29 & 66 & 72 & 30 & 32 & 50.9 & 5.6 & 1.3 & 0.7 & 5.0 & 1.0 & 2.5 & 2.3 & 7.2 & 3.2 & Considerable \\
\hline P6 & 81 & 100 & 50 & 33 & 57 & 36 & 22 & 26 & 50.5 & 7.1 & 4.7 & 0.4 & 5.7 & 0.9 & 1.6 & 2.0 & 6.0 & 3.5 & Considerable \\
\hline P7 & 46 & 32 & 69 & 20 & 100 & 49 & 35 & 41 & 49.0 & 4.0 & 2.0 & 0.5 & 3.8 & 1.5 & 2.0 & 2.5 & 9.1 & 3.2 & Considerable \\
\hline P8 & 77 & 0 & 86 & 88 & 69 & 16 & 66 & 86 & 61.1 & 6.7 & 0.7 & 0.6 & 13.8 & 1.0 & 1.2 & 3.8 & 18.1 & 5.8 & Considerable \\
\hline P9 & 1 & 33 & 0 & 0 & 97 & 13 & 18 & 2 & 20.6 & 0.2 & 2.0 & 0 & 0.9 & 1.4 & 1.1 & 1.8 & 1.3 & 1.1 & Moderate \\
\hline P10 & 0 & 23 & 0 & 0 & 89 & 4 & 17 & 0 & 16.6 & 0.1 & 1.6 & 0 & 0.8 & 1.3 & 0.9 & 1.8 & 0.9 & 0.9 & Low \\
\hline \multicolumn{20}{|c|}{ Dry season } \\
\hline P1 & 88 & 77 & 0 & 62 & 2 & 37 & 22 & 10 & 37.2 & 7.2 & 6.3 & 0 & 3.5 & 0 & 1.6 & 1.0 & 2.1 & 2.7 & Moderate \\
\hline P2 & 66 & 12 & 0 & 0 & 0 & 0 & 0 & 7 & 10.6 & 5.5 & 1.7 & 0 & 0.6 & 0 & 0.3 & 0.2 & 1.8 & 1.3 & Moderate \\
\hline P3 & 38 & 0 & 28 & 63 & 16 & 31 & 44 & 28 & 31.0 & 3.2 & 0.8 & 0.6 & 3.6 & 0.3 & 1.4 & 1.7 & 4.2 & 2.0 & Moderate \\
\hline P4 & 100 & 100 & 99 & 100 & 78 & 100 & 100 & 100 & 97.1 & 8.2 & 7.9 & 2.2 & 5.3 & 1.5 & 3.7 & 1.7 & 12.2 & 5.6 & Considerable \\
\hline P5 & 51 & 43 & 100 & 16 & 96 & 72 & 67 & 71 & 64.5 & 4.2 & 3.9 & 2.2 & 1.4 & 1.9 & 2.8 & 2.5 & 8.9 & 3.5 & Considerable \\
\hline P6 & 69 & 27 & 74 & 62 & 59 & 41 & 53 & 57 & 55.4 & 5.7 & 2.7 & 1.7 & 3.6 & 1.2 & 1.7 & 2.1 & 7.4 & 3.3 & Considerable \\
\hline P7 & 8 & 12 & 41 & 5 & 71 & 23 & 47 & 18 & 28.2 & 0.7 & 1.7 & 0.9 & 0.9 & 1.4 & 1.1 & 1.8 & 3.1 & 1.5 & Moderate \\
\hline P8 & 0 & 21 & 56 & 17 & 100 & 30 & 60 & 7 & 36.5 & 0.1 & 2.3 & 1.3 & 1.4 & 2.0 & 1.4 & 2.3 & 1.9 & 1.6 & Moderate \\
\hline P9 & 1 & 6 & 45 & 6 & 73 & 18 & 48 & 3 & 25.0 & 0.1 & 1.2 & 1.0 & 0.9 & 1.4 & 1.0 & 1.9 & 1.4 & 1.1 & Moderate \\
\hline P10 & 0 & 12 & 44 & 7 & 71 & 18 & 42 & 0 & 24.2 & 0.1 & 1.7 & 1.0 & 0.9 & 1.4 & 1.0 & 1.7 & 1.1 & 1.1 & Moderate \\
\hline
\end{tabular}

\subsection{Integration of geochemical and ecotoxicological data}

The cluster analyses showed 4 groups for the rainy season and 3 groups for the dry season (Fig. 3). In the rainy season, CA separated P1 from the resting sites, probably due to the low levels of metals and nutrients found. Sites P9 and P10 formed a second group that presented intermediate quantities of OM, a high percentage of muds, high nitrogen content, low phosphorus levels, and low metal concentrations (except in the case of $\mathrm{Cd}$ ). The third group included P2 and P8, with intermediate quantities of $\mathrm{OM}$ and muds, high nitrogen levels, high metal concentrations, and poor quality according to the toxicity tests. The fourth group included sites P3, P4, P5, P6, and P7 (mid-estuary) the sediment of which presented high metal concentrations and OM levels, moderate to high quantities of nitrogen and phosphorus, and variable toxicities. This CA suggests that other contaminants (not analyzed herein) may be contributing to the sediment toxicities, especially in the lower and upper portions of the JPE.

In the dry season, the first group included P4, P5 and P6, with high levels of metals, nutrients, and OM, as well as variable toxicities. The second group included P7 and P10, where the sediments presented low phosphorus concentrations, moderate concentrations of $\mathrm{OM}, \mathrm{Cr}$, $\mathrm{Cd}$ and $\mathrm{Pb}$, high amounts of muds, high total nitrogen content, and high toxicity. The third cluster included sites P1, P2 and P3, where metals, nutrients and OM were low but where the toxicities were moderate to high. As well as in the rainy season, non-measured contaminants may be contributing to the toxicity levels.

As sewage is discharged into the JPE, some pollutants would be expected to occur, as pharmaceuticals and personal care products (PPCPs), detergents, chloramines and other chemicals (Bound and Voulvoulis, 2005; Wise et al., 2011). A previous study found high concentrations of HPAs in sediments collected along the JPE (Queiroz, 2011), and since this group of substances is widely known as toxic and carcinogenic, they may have contributed to the observed toxicity. In addition, we measured the concentrations of ionized ammonia in the sediments and the concentrations reached levels capable of inducing negative biological effects; however three of test-organisms used in this study are relatively insensitive to ammonia. Campos et al. (2016) showed that in estuarine sediments rich in ammonia, inputs of low amounts of metals may induce sediment toxicity. Therefore, many chemicals may be present in JPE sediments, interacting with metals and contributing to the observed toxicity. Further studies should be conducted with the purpose of identify and quantify such substances.

The results of the FA-PCA for both campaigns are shown in Figs. 4 and 5 . For the results of the rainy season, the first three factors explained $74.82 \%$ of the variances. Each axis explained a relatively low percentage of variances (Table 6), which is expected in heterogeneous

Table 5

Results of the tests on sediments from the Jundiaí-Potengi Estuary and the experimental control (C) during the rainy and dry seasons. The values shown are the means.

\begin{tabular}{|c|c|c|c|c|c|c|c|c|c|c|c|c|c|}
\hline \multicolumn{3}{|c|}{ Rainy season } & & \multirow{2}{*}{$\begin{array}{r}\text { P1 } \\
0\end{array}$} & \multirow{2}{*}{$\frac{\mathrm{P} 2}{5}$} & \multirow{2}{*}{$\begin{array}{r}\text { P3 } \\
3.3\end{array}$} & \multirow{2}{*}{$\begin{array}{l}\text { P4 } \\
13.3\end{array}$} & \multirow{2}{*}{$\begin{array}{l}\text { P5 } \\
16.7\end{array}$} & \multirow{2}{*}{$\begin{array}{c}\text { P6 } \\
1.7\end{array}$} & \multirow{2}{*}{$\begin{array}{l}\text { P7 } \\
11.7\end{array}$} & \multirow{2}{*}{$\begin{array}{c}\text { P8 } \\
30\end{array}$} & \multirow{2}{*}{$\begin{array}{l}\text { P9 } \\
1.7\end{array}$} & \multirow{2}{*}{$\begin{array}{r}\text { P10 } \\
1.7\end{array}$} \\
\hline AT & $\%$ mortality & L. plumulosus & & & & & & & & & & & \\
\hline & & T. viscana & 10 & 73.3 & 83.3 & 30 & 33.3 & 33.3 & 46.7 & 40 & 76.7 & 36.7 & 56.7 \\
\hline \multirow[t]{2}{*}{$\mathrm{CT}$} & fecundity ((nauplii + copepodits)/female) & Nitocra sp. & 33.1 & 46.8 & 35.4 & 29.7 & 27.9 & 34.7 & 19.3 & 25.1 & 24.2 & 17.1 & 20.6 \\
\hline & $\%$ abnormal development & L. variegatus & 15 & 95.2 & 100 & 100 & 91.5 & 33.2 & 54.7 & 26.2 & 100 & 79.2 & 83.7 \\
\hline \multicolumn{14}{|c|}{ Dry season } \\
\hline \multirow{2}{*}{ AT } & $\%$ mortality & L. plumulosus & 1.7 & 5 & 3.3 & 1.7 & 16.7 & 21.7 & 20 & 15 & 13.3 & 10 & 45 \\
\hline & & T. viscana & 16.7 & 96.7 & 46.7 & 60 & 55 & 40 & 53.3 & 73.3 & 73.3 & 83.3 & 40 \\
\hline \multirow[t]{2}{*}{ CT } & fecundity ((nauplii + copepodits)/female) & Nitocra sp. & 43.7 & 35.6 & 37.5 & 17 & 33.4 & 22.7 & 18.6 & 34.7 & 20.7 & 36.5 & 22.1 \\
\hline & \% abnormal development & L. variegatus & 19.2 & 64.2 & 94.7 & 92.5 & 36.7 & 92 & 81 & 88.7 & 100 & 74.7 & 41.7 \\
\hline
\end{tabular}

AT: acute toxicity.

CT: chronic toxicity.

C: control. 
a)

Rainy season

Ward's method

Euclidean distances

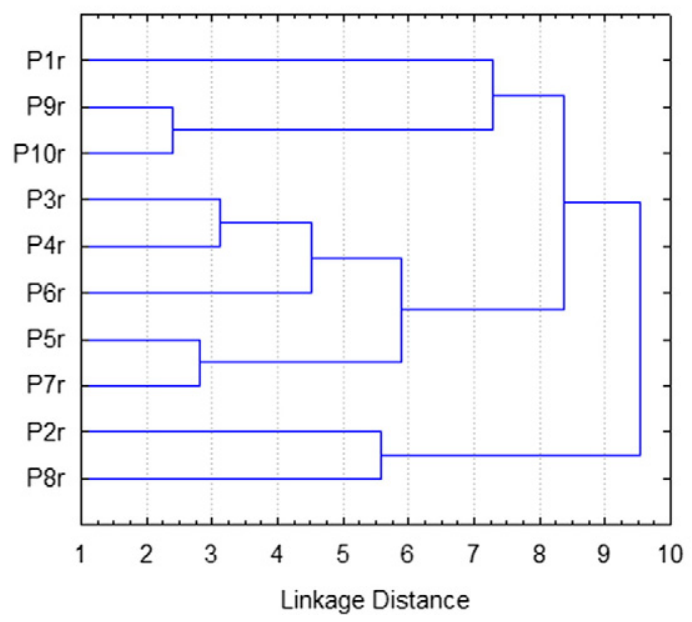

b)

Dry season

Ward's method

Euclidean distances

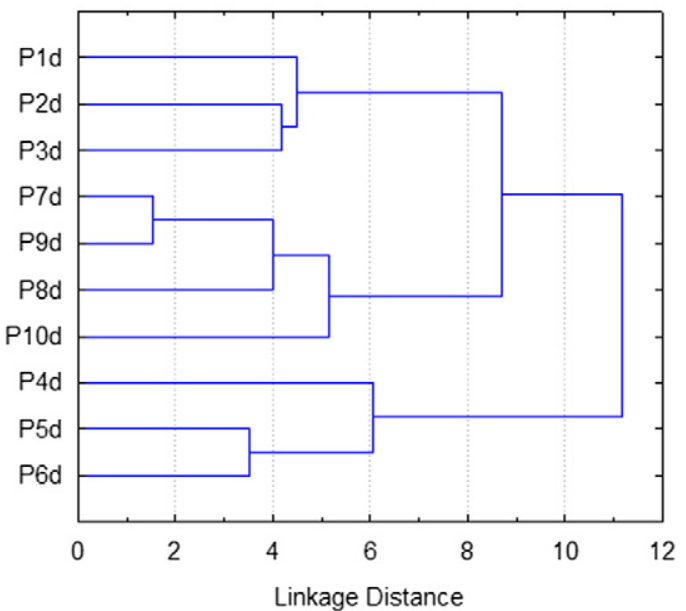

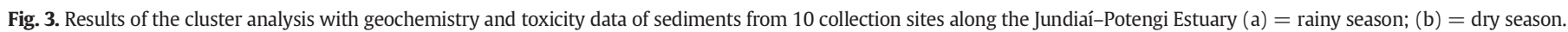

environments where interactions between variables are intense and complex. The first factor (F1) explained $34.19 \%$ of the variances and showed associations between nitrogen, $\mathrm{Cr}, \mathrm{Cu}, \mathrm{Pb}, \mathrm{Zn}$, and amphipod mortality (Table 6); sites P2 and P8 made the highest contribution to this factor (Fig. 5). Mn correlated negatively with F1, a finding which suggests that the positive correlations mentioned above indicate an anthropic component, since Mn naturally occurs in high concentrations and is not typically associated with human activity (Niencheski et al., 1994). These findings are consistent with the EF results, which showed enrichment of metals in sediments from P2 and P8 (Table 4). The second factor explained $26.38 \%$ of the variances and showed positive correlations with nitrogen, $\mathrm{Cr}, \mathrm{Cd}, \mathrm{Ni}, \mathrm{OM}$, and muds (Table 6). Negative correlations with this factor were obtained in the case of $T$. viscana mortality and abnormal sea urchin embryo development. Site P1 was the most important to F2 (Fig. 5). This result corroborates those from the CA and suggests that, during the rainy season, P1 is not directly influenced by the deposition of OM and muds or, consequently, by the

Rotation: Varimax normalized Extraction: Principal components - Rainy season

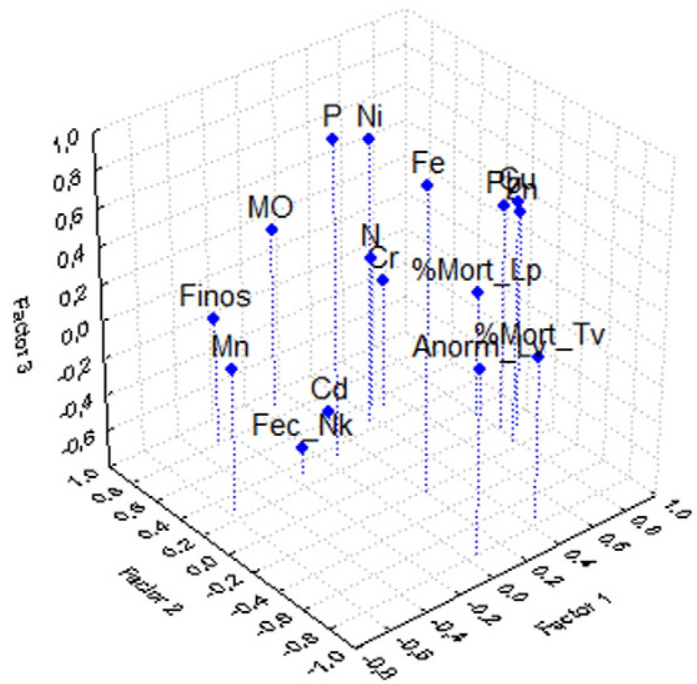

elements associated with suspended particles, such as nitrogen, $\mathrm{Cr}, \mathrm{Cd}$, and $\mathrm{Ni}$; under these conditions, toxicity may have been caused by unmeasured contaminants (Table 6 and Fig. 2). The third factor (F3) explained only $14.3 \%$ of the variances and showed an association between $\mathrm{Fe}, \mathrm{Cu}, \mathrm{Ni}, \mathrm{Pb}$, and phosphorus. This finding may indicate a common source for these elements, such as sewage or urban drainage. Copepod fecundity was found to be negatively correlated with this factor, a result which indicates that the elements above may be linked to chronic toxicity; on the other hand, the negative correlation observed in the case of $\mathrm{Cd}$ may be a mathematical artifact, since the concentrations of this element were low.

When the dry season was considered, the first three factors explained $78.95 \%$ of the variances (Fig. 5). The first factor explained $46.33 \%$ of the variances and showed positive correlation for $\mathrm{Fe}, \mathrm{Mn}, \mathrm{Cr}$, $\mathrm{Cu}, \mathrm{Ni}, \mathrm{Pb}, \mathrm{Zn}$, phosphorus, and OM (Table 6). Abnormal L. variegatus development was found to be negatively correlated with F1; thus, these results suggest that the main causes of toxicity for this species were

\section{Rotation: Varimax normalized}

\section{Extraction: Principal components - Dry season}

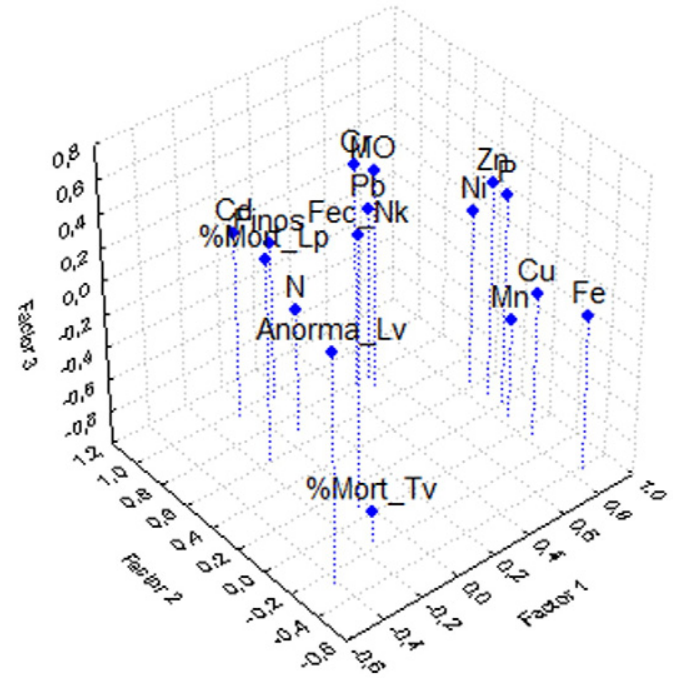

Fig. 4. Three-dimensional projection of geochemical and ecotoxicological variables from the Jundiaí-Potengi Estuary for the rainy and dry seasons after the factor analyses. 
Projection of the cases on the factor-plane $\left(\begin{array}{ll}1 \times 2 & 2\end{array}\right)$ Rainy season

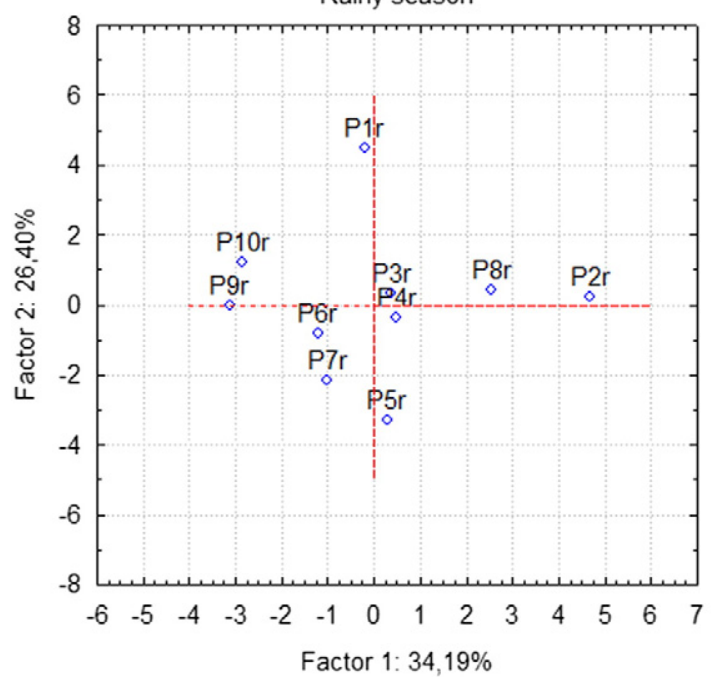

Projection of the cases on the factor-plane $\left(\begin{array}{ll}1 \times 2 & 2\end{array}\right)$ Dry season

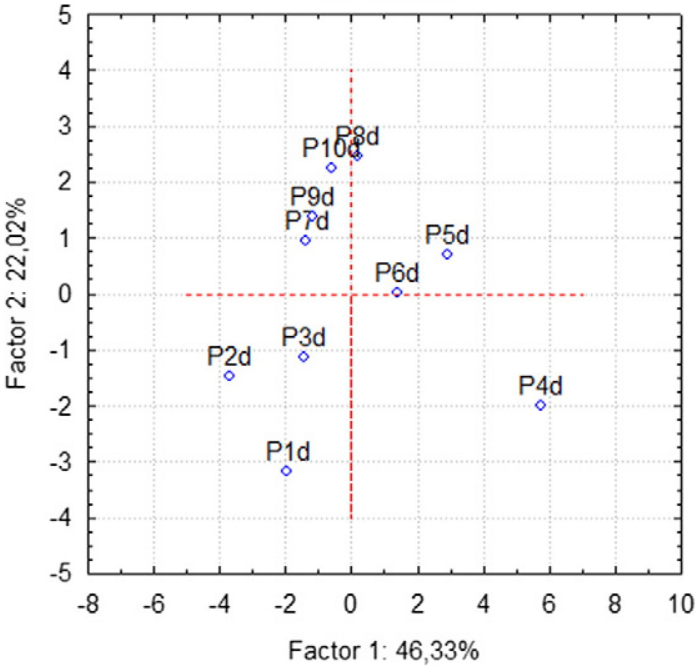

Fig. 5. Scores of the two first factors obtained in the factor analyses using geochemical and ecotoxicological variables of the Jundiaí-Potengi Estuary for the rainy season and the dry season.

unmeasured contaminants. Sites P4, P5, and P6 were the most important to this factor (Fig. 5). The results also suggest, at least partially, that the metals and phosphorus may have a natural source. Since sediments from $\mathrm{P} 4, \mathrm{P} 5$, and $\mathrm{P} 6$ presented the highest EF values, this portion of the JPE is likely being influenced by both natural and human inputs during the dry season. Moreover, sediments from P4 were not toxic in this campaign, which indicates that metals were not bioavailable. Chapman and Wang (2001) reported that the increased metal concentrations in relation to the background levels do not necessarily indicate toxicity. The second factor explained $22.01 \%$ of the variances and showed an association between nitrogen, $\mathrm{OM}$, muds, $\mathrm{Cr}, \mathrm{Cd}, \mathrm{Pb}, \mathrm{Ni}$, and L. plumulosus mortality (Table 6); thus, F2 essentially provides evidence of the human causes of environmental degradation and its effects. These correlations also showed that OM and muds are important geochemical carriers during the dry season, as suggested by Lacerda et al. (2012) in a study on other estuaries from the semi-arid coast of

Table 6

Eigenvalues and correlations obtained in the factor analysis-principal component analysis (FA-PCA) using geochemical and ecotoxicological data on sediments from the JundiaíPotengi Estuary from the rainy and dry seasons. Bold fonts indicate significant correlations (for a cut-off value of 0.40 ).

\begin{tabular}{|c|c|c|c|c|c|c|}
\hline \multirow[t]{2}{*}{ Variable } & \multicolumn{3}{|c|}{ Rainy season } & \multicolumn{3}{|c|}{ Dry season } \\
\hline & $\begin{array}{l}\text { Factor } \\
1\end{array}$ & $\begin{array}{l}\text { Factor } \\
2\end{array}$ & $\begin{array}{l}\text { Factor } \\
3\end{array}$ & $\begin{array}{l}\text { Factor } \\
1\end{array}$ & $\begin{array}{l}\text { Factor } \\
2\end{array}$ & $\begin{array}{l}\text { Factor } \\
3\end{array}$ \\
\hline $\mathrm{Fe}$ & 0.20 & -0.22 & 0.84 & 0.87 & -0.40 & -0.06 \\
\hline Mn & -0.56 & 0.28 & -0.03 & 0.85 & 0.12 & -0.39 \\
\hline $\mathrm{Cr}$ & 0.51 & 0.54 & -0.10 & 0.48 & 0.79 & 0.35 \\
\hline $\mathrm{Cu}$ & 0.79 & -0.15 & 0.51 & 0.85 & -0.05 & -0.13 \\
\hline $\mathrm{Cd}$ & 0.20 & 0.57 & -0.73 & -0.06 & 0.97 & 0.13 \\
\hline $\mathrm{Ni}$ & 0.38 & 0.46 & 0.73 & 0.88 & 0.43 & 0.07 \\
\hline $\mathrm{Pb}$ & 0.82 & -0.02 & 0.41 & 0.54 & 0.79 & 0.06 \\
\hline $\mathrm{Zn}$ & 0.89 & -0.06 & 0.38 & 0.88 & 0.31 & 0.30 \\
\hline $\mathrm{N}$ & 0.47 & 0.58 & 0.02 & 0.08 & 0.70 & -0.25 \\
\hline $\mathrm{P}$ & 0.08 & 0.34 & 0.89 & 0.89 & 0.22 & 0.27 \\
\hline MO & 0.11 & 0.91 & 0.17 & 0.53 & 0.72 & 0.32 \\
\hline Fines & -0.28 & 0.83 & -0.12 & 0.13 & 0.97 & -0.04 \\
\hline Mort_L. plumulosus & 0.80 & 0.16 & -0.13 & -0.14 & 0.61 & 0.23 \\
\hline Mort_T. viscana & 0.45 & -0.75 & 0.08 & -0.13 & -0.16 & -0.81 \\
\hline Fec_Nitocra & -0.14 & 0.31 & -0.66 & -0.04 & 0.07 & 0.63 \\
\hline Abnormal_L. variegatus & 0.07 & -0.79 & 0.19 & -0.42 & -0.27 & 0.38 \\
\hline Eigenvalues & 5.47 & 4.22 & 2.27 & 7.41 & 3.52 & 1.69 \\
\hline$\%$ Total variance & 34.19 & 26.39 & 14.23 & 46.33 & 22.01 & 10.6 \\
\hline \% Cumulative var. & 34.19 & 60.59 & 74.82 & 46.33 & 68.34 & 78.95 \\
\hline
\end{tabular}

Brazil. Iron was found to be negatively correlated with to F2, a finding which corroborates that the source of metals was human activity. The third factor explained $10.60 \%$ of the variances. T. viscana mortality was found to be negatively correlated with this factor, while the abnormal sea-urchin embryo development was found to be positively correlated. This result suggests that, during the dry season, other variables (unmeasured contaminants, confounding factors) contributed to sediment toxicity.

The analyses showed that sediments from the JPE are especially enriched by the mid-estuarine portion. We were not able to not detect clear gradients along the estuary, because the JPE presents multiple contamination sources that create a complex and heterogeneous geochemical and ecotoxicological dynamic. A similar situation was observed by Rodrigues et al. (2013) in Guaratuba Bay (southern Brazil), as well as in other sites around the world (Du et al., 2012; Araujo et al., 2013; Roig et al., 2015). We also observed that, in both seasons, the sediment quality of the JPE was altered, and that nutrients and metals have both natural and anthropic sources, similar to other estuaries from the semi-arid coast of Brazil (Marins et al., 2002; Lacerda et al., 2007, 2012). Metal concentrations tended to occur in sediments from sites located close to sources of human activity, a finding which corroborates previous data on the JPE (Silva et al., 2001, 2003, 2006). These other studies reported that the main sources of pollution for this estuary are untreated sewage, industrial effluents, and agricultural residues, which include fertilizers and pesticides. Further studies are recommended to determine which chemical groups are responsible for the sediment toxicity in the JPE, as well as to determine if the microbenthic community is being affected by the contaminants.

\section{Conclusions}

Our results indicate that the sediments from the JPE present some degree of degradation. These sediments are toxic and enriched by metals and nutrients, and this situation is produced by a combination of natural sources and human activity. The mid-estuary is considered to be the most altered portion of the JPE, regardless of the season. Conditions are worse during the rainy period, when urban and agricultural runoffs are more intense and carry other contaminants to the estuary. The dry season shows a more clear relationship between contamination and toxicity, because the conditions favor the retention of contaminants within the estuary. In this study, toxicities did not correlate highly with 
metal concentrations, a result which suggests that unmeasured contaminants are contributing to the environmental degradation.

\section{Acknowledgments}

The authors would like to thank Mr. Espedito Carvalho for providing the map in a GIS environment; both the NEPEA Laboratory of São Paulo State University (UNESP) and the Federal University of Rio Grande do Norte (UFRN) Ecotoxicology Lab staff for the technical assistance; to the Rio Grande do Norte Federal Institute for Science and Technology Education (IFRN), and the Secretary of Professional and Technological Education from the Ministry of Education (SETEC-MEC) for the technical and financial support (grant No. 07/2013-2 and No. 001/2012-1, respectively). Dr. D. Abessa thanks the Brazilian National Council for Scientific and Technological Development (CNPq) for their financial support (grant No. 479899/2013-4).

\section{Appendix A. Supplementary data}

Supplementary data to this article can be found online at http://dx. doi.org/10.1016/j.marpolbul.2016.02.009.

\section{References}

Abessa, D.M.S., Carr, R.S., Rachid, B.R.F., Sousa, E.C.P.M., Hortelani, M.A., Sarkis, J.E., 2005. Influence of a Brazilian sewage outfall on the toxicity and contamination of adjacent sediments. Mar. Pollut. Bull. 50 (8), 875-885.

Abessa, D.M.S., Carr, R.S., Sousa, E.C.P.M., Rachid, B.R.F., Zaroni, L.P., Pinto, Y.A., Gasparro M.R., Bícego, M.C., Hortellani, M.A., Sarkis, J.E.S., Muniz, P., 2008. Integrative ecotoxicological assessment of a complex tropical estuarine st. In: Hoffer, T.N. (Ed.), Marine Pollution: New Research. Nova Science, New York, pp. 125-159.

ABNT - Associação Brasileira de Normas e Técnicas, 2012. ABNT/NBR 15350. Ecotoxicologia aquática: Toxicidade crônica de curta duração - Método de ensaio com ouriço do mar (Echinodermata: Echinoidea) (21 pp.).

ABNT - Associação Brasileira de Normas Técnicas, 1988. ABNT/NBR 7181. Solo: análise granulométrica (13 pp.).

ABNT - Associação Brasileira de Normas Técnicas, 2008. ABNT/NBR 15638. Qualidade da Água: Determinação da toxicidade aguda de sedimentos marinhos ou estuarinos com anfípodos (17 pp.).

Adamo, P., Arienzo, M., Imperato, M., Naimo, D., Nardi, G., Stanzione, D., 2005. Distribution and partition of heavy metals in surface and sub-surface sediments of Naples city port. Chemosphere 61 (6), 800-809.

Adams, William, Kimerle, Richard, Barnett, J., 1992. Sediment quality and aquatic life assessment. Environ. Sci. Technol. 26 (10), 1864-1875.

Alencar, J. De, Franco, R., Lima, D.S., Cunha, L., Souza, D., 2005. Metais pesados em água do rio Jundiaí-Macaíba/RN. Rev. Geol. 18 (2), 131-142.

Ambrozevicius, A.P., Abessa, D.M.S., 2008. Acute toxicity of waters from the urban drainage channels of Santos (São Paulo, Brazil). Pan-Am. J. Aquat. Sci. 3 (2), 108-115.

Anderson, B.S., Hunt, J.W., Phillips, B.M., Fairey, R., Puckett, H.M., Stephenson, M., Taberski, K., Newman, J., Tjeerdema, R.S., 2001. Influence of sample manipulation on contaminant flux and toxicity at the sediment-water interface. Mar. Environ. Res. 51 (3), 191-211.

Aprile, F.M., Bouvy, M., 2008. Distribution and enrichment of heavy metals in sediments at the Tapacurá river basin, Northeastern Brazil. Braz. J. Aquat. Sci. Technol. 12, 1-8.

Araújo, C.V.M., Diz, F.R., Laiz, I., Lubián, L.M., Blasco, J., Moreno-Garrido, I., 2009. Sediment integrative assessment of the Bay of Cádiz (Spain): an ecotoxicological and chemical approach. Environ. Int. 35 (6), 831-841.

Araujo, G.S., Moreira, L.B., Morais, R.D., Davanso, M.B., Garcia, T.F., Cruz, a C.F., Abessa, D.M.S., 2013. Ecotoxicological assessment of sediments from an urban marine protected area (Xixová-Japuí State Park, SP, Brazil). Mar. Pollut. Bull. 75 (1-2), 62-68.

Bartoli, G., Papa, S., Sagnella, E., Fioretto, A., 2012. Heavy metal content in sediments along the Calore river : relationships with physical e chemical characteristics. J. Environ. Manag. 95, S9-S14.

Boski, T., Bezerra, F.H.R., de Fátima Pereira, L., Souza, A.M., Maia, R.P., Lima-Filho, F.P., 2015. Sea-level rise since $8.2 \mathrm{ka}$ recorded in the sediments of the Potengi-Jundiai Estuary, NE Brasil. Mar. Geol. 365, 1-13.

Bound, J.P., Voulvoulis, N., 2005. Household disposal of pharmaceuticals as a pathway for aquatic contamination in the United Kingdom. Environ. Health Perspect. 113 (12), 1705-1711.

Boyd, C.E., Massaut, L., 1999. Risks associated with the use of chemicals in pond aquaculture. Aquac. Eng. 20 (2), 113-132.

Burton, G.A., Johnston, E.L., 2010. Assessing contaminated sediments in the context of multiple stressors. Environ. Toxicol. Chem. 29 (12), 2625-2643.

Burton Jr., G.A., 1992. Assessing contaminated aquatic sediments. Environ. Sci. Technol. $26,1862-1875$.

Buruaem, L.M., Araujo, G.S., Rosa, P.A., Nicodemo, S.C., Porto, V.F., Fonseca, J.R., Cruz, J.V., Medeiros, G.F., Abessa, D.M.S., 2013b. Assessment of sediment toxicity from the Areia Branca off-shore harbor and the Potengi river estuary (RN), northeastern Brazil. Pan-Am. J. Aquat. Sci. 8, 312-326.
Buruaem, L.M., de Castro, Í.B., Hortellani, M.A., Taniguchi, S., Fillmann, G., Sasaki, S.T., Petti, M.A.V., Sarkis, J.E.S., Bícego, M.S., Maranho, L.A., Davanso, M.B., Nonato, E.F., Cesar, A., Costa-Lotufo, L.V., Abessa, D.M.D.S., 2013a. Integrated quality assessment of sediments from harbour areas in Santos-São Vicente Estuarine System, Southern Brazil. Estuar. Coast. Shelf Sci.

Buruaem, L.M., Hortellani, M.A., Sarkis, J.E., Costa-Lotufo, L.V., Abessa, D.M.S., 2012. Contamination of port zone sediments by metals from Large Marine Ecosystems of Brazil. Mar. Pollut. Bull. 64 (3), 479-488.

Campos, B.G., Cruz, A.C.F., Buruaem, L.M., Machado, W.V.T., Abessa, D.M.S., 2016. Using a tiered approach based on ecotoxicological techniques to assess the ecological risks of contamination in a subtropical estuarine protected area. Sci. Total Environ. 544, 564-573.

Carvalho, C.E.V., Salomão, M.S.M.B., Molisani, M.M., Rezende, C.E., Lacerda, L.D., 2002. Contribution of a medium-sized tropical river to the particulate heavy-metal load for the South Atlantic Ocean. Sci. Total Environ. 284, 85-93.

Casado-Martínez, M.C., Forja, J.M., DelValls, T.A., 2009. A multivariate assessment of sediment contamination in dredged materials from Spanish ports. J. Hazard. Mater. 163, 1353-1359.

Cesar, A., Marin, A., Marin-Guirao, L., Vita, R., 2004. Amphipod and sea urchin tests to assess the toxicity of Mediterranean sediments: the case of Portman Bay. Sci. Mar. 68, 205-213.

Cesar, A., Marín, A., Marin-Guirao, L., Vita, R., Lloret, J., DelValls, T.A., 2009. Integrative ecotoxicological assessment of sediment in Portmán Bay (southeast Spain). Ecotoxicol. Environ. Saf. 72 (7), 1832-1841.

Chapman, P.M., Wang, F., 2001. Assessing sediment contamination in estuaries. Environ. Toxicol. Chem./SETAC 20 (1), 3-22.

Chapman, P.M., Wang, F., Adams, W.J., Utah, K., Corporation, C., Box, P.O., Green, A., 1999. Appropriate applications of sediment quality values for metals and metalloids. Environ. Sci. Technol. 33, 3937-3941.

Chen, Z., Saito, Y., Kanai, Y., Wei, T., Li, L., Yao, H., Wang, Z., 2004. Low concentration of heavy metals in the Yangtze estuarine sediments, China: a diluting setting. Estuar. Coast. Shelf Sci. 60 (1), 91-100.

Choueri, R.B., Cesar, a, Torres, R.J., Abessa, D.M.S., Morais, R.D., Pereira, C.D.S., Nascimento M.R.L., Mozeto, A.A., Riba, I., DelValls, T.A., 2009a. Integrated sediment quality assessment in Paranaguá Estuarine System, Southern Brazil. Ecotoxicol. Environ. Saf. 72 (7) 1824-1831.

Choueri, R.B., Cesar, A., Abessa, D.M.S., Torres, R.J., Morais, R.D., Riba, I., Pereira, C.D.S. Nascimento, M.R.L., Mozeto, A.A., DelValls, T.A., 2009b. Development of site-specific sediment quality guidelines for North and South Atlantic littoral zones: comparison against national and international sediment quality benchmarks. J. Hazard. Mater. 170 (1), 320-331.

Choueri, R.B., Cesar, a., Abessa, D.M.S., Torres, R.J., Riba, I., Pereira, C.D.S., Nascimento M.R.L., Morais, R.D., Mozeto, A.A., Delvalls, T.A., 2010. Harmonised framework for ecological risk assessment of sediments from ports and estuarine zones of North and South Atlantic. Ecotoxicology 19 (4), 678-696.

Comrey, A.L., Lee, H.B., 1992. A First Course in Factor Analysis. second ed. L. Erlbaum Associates, Hillsdale.

CONAMA - Conselho Nacional de Meio Ambiente. Brasil, 2012. Resolução nº 454, de 1 de novembro de 2012. Disponível em http://www.mma.gov.br/port/conama/legiabre. cfm?codlegi=693 (acessado: 08.11.13).

Cooper, D.C., Morse, J.W., 1998. Biogeochemical controls on trace metal cycling in anoxic marine sediments. Environ. Sci. Technol. 32 (3), 327-330.

Costanza, R., D'Arge, R., de Groot, R., Farber, S., Grasso, M., Hannon, B., Limburg, K., Naeem, S., O'Neil, R.V., Paruelo, J., Raskin, R.G., Sutton, P., van den Belt, M., 1997. The value of the world's ecosystem services and natural capital. Nature 387 (6630), 253-260.

Cunha, P.E.V., 2010. Aplicação da metodologia para estimativa do fator de emissão nutrientes e metais pesados - para avaliar a contribuição dos efluentes de carcinicultura no estuário do Rio Potengi, Natal (RN) (Tese de doutorado) Universidade de São Paulo, Escola de Engenharia de São Carlos (Disponível em: http://www.teses.usp.br/teses/disponiveis/18/18138/tde-02062010-093706/pt-br. php(acessado 08.11.13)).

Dantas, A.S., 2009. Análise de sedimento de fundo: uma amostragem representativa do estuário Potengi/RN (Master of Sciences Dissertation) Universidade Federal do Rio Grande do Norte, Natal, Brazil (114 pp.).

DelValls, T.A., Andres, A., Belzunce, M.J., Buceta, J.L., Casado-Martinez, M.C., Castro, R., Riba, I., Viguri, J.R., Blasco, J., 2004. Chemical and ecotoxicological guidelines for managing disposal of dredged material. TrAC Trends Anal. Chem. 23 (10-11), 819-828.

Diegues, A.C., 2001. Ecologia humana e planejamento costeiro. $2^{2}$ ed. NUPAUB-USP, São Paulo (225 pp.)

Du, J., Mehler, W.T., Lydy, M.J., You, J., 2012. Toxicity of sediment-associated unresolved complex mixture and its impact on bioavailability of polycyclic aromatic hydrocarbons. J. Hazard. Mater. 203-204, 169-175.

Elliott, M., Quintino, V., 2007. The estuarine quality paradox, environmental homeostasis and the difficulty of detecting anthropogenic stress in naturally stressed areas. Mar. Pollut. Bull. 54, 640-645.

EMBRAPA - Empresa Brasileira de Pesquisa Agropecuária, 1998. Análises químicas para avaliação da fertilidade do solo. Métodos Usados na Embrapa Solos 40, pp. 1414-8153.

EMPARN - Empresa de Pesquisa Agropecuária do RN, 2013. Boletins de precipitação da estação Natal. Séries 2013. Disponível em http://189.124.135.176/monitoramento/ 2013/acumulapr.htm (acessado: 27.02.14).

Fonseca, E.M., Neto, J.A.B., Silva, C.G., Mcalister, J.J., Smith, B.J., Fernandez, M.A., 2013. Estuarine, coastal and shelf science stormwater impact in Guanabara Bay/RJ: evidences of seasonal variability in the dynamic of the sediment heavy metals. Estuar. Coast. Shelf Sci. 130, 161-168.

Freire, G.S.S., Lima, S., Maia, L.P., Lacerda, L.D., 2004. Geochemistry of continental shelf sediments of the Ceará coast, NE Brazil. In: Lacerda, L.D., Santelli, R.E., Duursma, 
E.K., Abrão, J.J. (Eds.), Facets of Environmental Geochemistry in Tropical and Subtropical Environments. Springer Verlag. Berlin, Germany, pp. 365-378 (384 pp.).

Gao, X., Chen, C.T.A., 2012. Heavy metal pollution status in surface sediments of the coastal Bohai Bay. Water Res. 46 (6), 1901-1911.

Gonçalves, S.F., Calado, R., Gomes, N.C.M., Soares, A.M.V.M., Loureiro, S., 2013. An ecotoxicological analysis of the sediment quality in a European Atlantic harbor emphasizes the current limitations of the Water Framework Directive. Mar. Pollut. Bull. 72 (1), 197-204.

Grasshoff, K., Kremling, K., Ehrardt, M., 1999. Methods of Sewater Analysis. Weinheim, Wiley VCH Verlag (600 pp.).

Guedes, J.A., 2012. Teores geoquímicos em sedimentos de fundo do Rio Jundiaí, Macaíba/ RN. Braz. Geogr. J. 3 (1), 70-79.

Gupta, A., Rai, D.K., Pandey, R.S., Sharma, B., 2009. Analysis of some heavy metals in the riverine water, sediments and fish from river Ganges at Allahabad. Environ. Monit. Assess. 157, 449-458.

IBGE - Instituto Brasileiro de Geografia e Estatística, 2014. Estimativas populacionais dos municípios em 2014. Disponível em http://www.ibge.gov.br/home/presidencia/ noticias/pdf/analise_estimativas_2014.pdf (acessado: 07.01.15).

IDEMA - Instituto de Desenvolvimento Sustentável e Meio Ambiente do Rio Grande do Norte, 2008b. Cargas Industriais Do estuário Do Potengi Com vazão - 2007. IDEMA, $\mathrm{Natal} / \mathrm{RN}(4 \mathrm{pp}$.).

Idris, A.M., 2008. Combining multivariate analysis and geochemical approaches for assessing heavy metal level in sediments from Sudanese harbors along the Red Sea coast. Microchem. J. 90 (2), 159-163.

Islam, S., Ahmed, K., Raknuzzaman, M., 2015. Heavy metal pollution in surface water and sediment : a preliminary assessment of an urban river in a developing country. Ecol. Indic. 48, 282-291.

Krull, M., Abessa, D.M.S., Hatje, V., Barros, F., 2014. Integrated assessment of metal contamination in sediments from two tropical estuaries. Ecotoxicol. Environ. Saf. 106 195-203.

Lacerda, L.D., Marins, R.V., 2005. Geoquímica de sedimentos e o monitoramento de metais na plataforma continental nordeste oriental do Brasil. Geochem. Bras. 20, 123-135.

Lacerda, D., Gustavo, A., Parente, L., Augusto, C., Marcos, E., Cunha, S., 2006a. Relative importance of nitrogen and phosphorus emissions from shrimp farming and other anthropogenic sources for six estuaries along the NE Brazilian coast. 253, 433-446.

Lacerda, L.D., Santos, J.A., Madrid, R.M., 2006b. Copper emission factors from intensive shrimp aquaculture. Mar. Pollut. Bull. 52, 1784-1832.

Lacerda, L.D., Menezes, M.O.T., Molisani, M.M., 2007. Changes in mangrove extension at the Pacoti River estuary, CE, NE Brazil due to regional environmental changes between 1958 and 2004. Biota Neotropica 7 (3), 67-72.

Lacerda, L.D., Marins, R.V., Dias, F.J.S., Soares, T.M., 2012. O Paradoxo Árrtico: Impacto das Mudanças Climáticas Sobre Rios Árticos e do Semiárido Aumentam a Exportação de Mercúrio para o Oceano. Rev. Virtual Quim. 4 (4), 456-463.

Langston, W.J., Pope, N.D., Jonas, P.J.C., Nikitic, C., Field, M.D.R., Dowell, B., Shillabeer, N., Swarbrick, R.H., Brown, A.R., 2010. Contaminants in fine sediments and their consequences for biota of the Severn Estuary. Mar. Pollut. Bull. 61 (1-3), 68-82.

Lau, S., 2000. The significance of temporal variability in sediment quality for contamination assesment in a coastal wetland. Water Res. 34 (2), 379-386.

Lopes, R.B., 2012. Metais pesados no caranguejo Ucides cordatus (Linnaeus, 1763) e ecotoxicologia de sedimentos do estuário dos rios Jundiaí e Potengi - RN (Master of Science Dissertation) Universidade Federal do Rio Grande do Norte, Natal, Brazil (87 pp.).

Loska, K., Cebula, J., Pelczar, J., Wiechuła, D., Kwapuliński, J., 1997. Use of enrichment and contamination factors together with geoaccumulation indexes to evaluate the content of $\mathrm{Cd}, \mathrm{Cu}$, and $\mathrm{Ni}$ in the Rybnik water Reservoir in Poland. Water Air Soil Pollut. 93 (1-4), 347-365.

Loska, K., Wiechuła, D., 2003. Application of principal component analysis for the estimation of source of heavy metal contamination in surface sediments from the Rybnik Reservoir. Chemosphere 51, 723-733.

Lotufo, G.R., Abessa, D.M.S., 2002. Testes de toxicidade com sedimentos total e água intersticial estuarinos utilizando copépodos bentônicos. In: Nascimento, I.A., Sousa, E.C.P.M., Nipper, M.G. (Eds.), Métodos em Ecotoxicologia Marinha: Aplicações no Brasil cap. 13. Artes Gráficas e Indústria Ltda, São Paulo, pp. 151-162.

Machado, W., Moscatelli, M., Rezende, L.G., Lacerda, L.D., 2002. Mercury, zinc, and copper accumulation in mangrove sediments surrounding a large landfill in southeast Brazil. Environ. Pollut. (Barking, Essex : 1987) 120 (2), 455-461.

Mackenzie, W.R., Chou, F.L., 1993. Interactions of C, N, P and S biogeochemical cycles and global changes. Global Environmental Changes Series I vol. 4.

Marins, R.V., Paula Filho, F.J., Eschrique, S.A., Lacerda, L.D., 2011. Anthropogenic sources and distribution of phosphorus in sediments from the Jaguaribe River estuary, NE, Brazil. Braz. J. Biol 71 (3), 673-678.

Marins, R.V., José, F., Filho, D.P., Rodrigues, R., Lacerda, L.D., 2004. Total mercury distribution as a proxy of urban and industrial pollution along the Brazilian. Quím. Nova 27 (5), 763-770.

Marins, R.V., Lacerda, L.D., Mounier, S., Paraquetti, H.H.M., Marques, W.S., 2002 Caracterização hidroquímica, distribuição e especiação de mercúrio nos estuários dos rios Ceará e Pacoti, Região Metropolitana de Fortaleza, Ceará, Brasil. Geochim. Bras. 16, 37-48.

Marques, W.S., Sial, A.N., Menor, E.A., Ferreira, V.P., Freire, G.S.S. Lima, A.M.E., Manso, A.V 2008. Principal component analysis (PCA) and mineral associations of litoraneous facies of continental shelf carbonates from northeastern Brazil. Cont. Shelf Res. 28 (20), 2709-2717.

Marshall, S., Pettigrove, V., Carew, M., Hoffmann, A., 2010. Isolating the impact of sediment toxicity in urban streams. Environ. Pollut. (Barking, Essex : 1987) 158 (5), $1716-1725$.

Medeiros, M.L., 2009. Estudo Multitemporal da Dinâmica Espacial do estuário Potengi/RN utilizando como base os dados de Sensoriamento Remoto (Dissertação de Mestrado)
Universidade Federal do Rio Grande do Norte, Centro de Ciências Humanas, Letras e Artes (Disponível em: http://repositorio.ufrn.br:8080/jspui/handle/123456789/ 18888. (acessado: 09.02.14)).

Melo, S.L.R., Abessa, D.M.S., 2002. Teste de toxicidade com sedimentos marinhos utilizando anfípodos. In: Nascimento, I.A., Sousa, E.C.P.M., Nipper, M.G. (Eds.), Métodos em Ecotoxicologia Marinha: Aplicações no Brasil cap. 14. Artes Gráficas e Indústria Ltda, São Paulo, pp. 163-178.

Nascimento, F.S., Freire, G.S.S., Miola, B., 2010. Geochemistry of marine sediments of the Brazilian northeastern. Braz. J. Oceanogr. 58, 1-11.

Nicolau, R., Galera-Cunha, A., Lucas, Y., 2006. Transfer of nutrients and labile metals from the continent to the sea by a small Mediterranean river. Chemosphere 63 (3), 469-476.

Niencheski, L.F., Windom, H.L., Smith, R., 1994. Distribution of particulate trace metal in the southern part of the Patos Lagoon estuary. Aquat. Ecosyst. Health Manag. 28 (2), 96-102.

Nilin, J., Moreira, L.B., Aguiar, J.E., Marins, R., de Souza Abessa, D.M., da Cruz Lotufo, T.M., Costa-Lotufo, L.V., 2013. Sediment quality assessment in a tropical estuary: the case of Ceará River, Northeastern Brazil. Mar. Environ. Res. 91, 89-96.

Nipper, M.G., 1997. The development and application of sediment toxicity tests for regulatory purposes. Microscale Testing in Aquatic Toxicology: Advances, Techniques and Practice vol. 43. CRC Press, Boca Raton, FL, pp. 631-646.

Otero, X.L., Macias, F., 2002. Variation with depth and season in metal sulfides in salt marsh soils. Biogeochemistry 61 (3), 247-268.

Paula Filho, F.J., Marins, R.V., Lacerda, L.D., Aguiar, J.E., Peres, T.F., 2015. Background values for evaluation of heavy metal contamination in sediments in the Parnaíba River Delta estuary, NE/Brazil. Mar. Pollut. Bull. 91 (2), 424-428.

Pekey, H., 2006. The distribution and sources of heavy metals in Izmit Bay surface sediments affected by a polluted stream. Mar. Pollut. Bull. 52 (10), 1197-1208.

Petrovic, M., Gonzalez, S., Barceló, D., 2003. Analysis and removal of emerging contaminants in wastewater and drinking water. Trends Anal. Chem. 22 (10), 685-696.

Pusceddu, F.H., Alegre, G.F., Pereira, C.D.S., Cesar, A., 2007. Avaliação da Toxicidade do Sedimento do Complexo Estuarino de Santos Empregando Ouriços-do-mar Lytechinus variegatus (Echinoidea: Echinodermata). J. Braz. Soc. Ecotoxicol. 2, 237-242.

Queiroz, M.S.M., 2011. Hidrocarbonetos policíclicos aromáticos em sedimentos de fundo do estuário do Rio Potengi, região da grande Natal (RN): implicações ambientais (Master of Science Dissertation) Universidade Federal do Rio Grande do Norte, Natal, Brazil (99 pp.).

Ré, A., Freitas, R., Sampaio, L., Rodrigues, A.M., Quintino, V., 2009. Chemosphere Estuarine sediment acute toxicity testing with the European amphipod. Chemosphere 76 (10), 1323-1333.

Rodrigues, S.K., Abessa, D.M.S., Machado, E.C., 2013. Geochemical and ecotoxicological assessment for estuarine surface sediments from Southern Brazil. Mar. Environ. Res. 91, 68-79 (5)

Roig, N., Sierra, J., Nadal, M., Moreno-Garrido, I., Nieto, E., Hampel, M., Galego, E.P., Schumacher, M., Blasco, J., 2015. Assessment of sediment ecotoxicological status as a complementary tool for the evaluation of surface water quality: the Ebro river basin case study. Sci. Total Environ. 503-504, 269-278.

Savage, C., Thrush, S.F., Lohrer, A.M., Hewitt, J.E., 2012. Ecosystem services transcend boundaries: estuaries provide resource subsidies and influence functional diversity in coastal benthic communities. PLoS One 7 (8), 1-9.

SEPLAN - Secretaria de Planejamento e Finanças do Rio Grande do Norte, 2013d. Perfil do Rio Grande do Norte. Natal/RN 191 pp. Disponível em http://www.seplan.rn.gov.br/ arquivos/download/PERFIL\%20DO\%20RN.pdf (acessado: 02.04.13).

Silva, C.A.R., Dávalos, P.B., Sternberg, S.L., Souza, F.E.S., Spyrides, M.H.C., Lucio, P.S., 2010. The influence of shrimp farms organic waste management on chemical water quality. Estuar. Coast. Shelf Sci. 90 (1), 55-60.

Silva, C.A.R., Oliveira, S.R., Rêgo, R.D.P., Mozeto, A.A., 2007. Dynamics of phosphorus and nitrogen through litter fall and decomposition in a tropical mangrove forest. Mar. Environ. Res. 64 (4), 524-534.

Silva, C.A.R., Rainbow, P.S., Smith, B.D., 2003. Biomonitoring of Trace Metal Contamination in Mangrove-lined Brazilian Coastal Systems Using the Oyster Crassostrea Rhizophorae : Comparative Study of Regions Affected by Oil, Salt Pond and Shrimp Farming Activities. pp. 199-206.

Silva, C.A.R., Rainbow, P.S., Smith, B.D., Santos, Z.L., 2001. Biomonitoring of trace metal contamination in the potengi estuary, Natal (Brazil), using the oyster Crassostrea rhizophorae, a local food source. Water Res. 35 (17), 4072-4078.

Silva, C.A.R., Silva, A.P., Oliveira, S.R., 2006. Concentration, stock and transport rate of heavy metals in a tropical red mangrove, Natal, Brazil. Mar. Chem. 99 (1-4), 2-11.

Sindern, S., Lima, R.F.S., Schwarzbauer, J., Petta, R.A., 2007. Anthropogenic heavy metal signatures for the fast growing urban area of Natal (NE-Brazil). Environ. Geol. 52, 731-737.

Singh, M., Ansari, A.A., Müller, G., Singh, I.B., 1997. Heavy metals in freshly deposited sediments of the Gomati River (a tributary of the Ganga River ): effects of human activities. Environ. Geol. 29 (February), 246-252.

Souza, F.E.S., Silva, C.A.R., 2011. Ecological and economic valuation of the Potengi estuary mangrove wetlands (NE, Brazil) using ancillary spatial data. J. Coast. Conserv. 15 (1), 195-206.

Tam, N.F., Wong, Y.S., 2000. Spatial variation of heavy metals in surface sediments of Hong Kong mangrove swamps. Environ. Pollut. (Barking, Essex : 1987) 110 (2), 195-205 (3).

Tavares, J.L., Calado, A.L.A., Fioravanti, R., 2014. Estudos iniciais para uso do índice TRIX para análise do nível de eutrofização no estuário do Rio Potengi-Natal-RN-Brasil. AIDIS 7 (3), 297-308

Torres, R.J., Abessa, D.M.S., Santos, F.C., Maranho, L.A., Davanso, M.B., Nascimento, M.R.L. Mozeto, A.A., 2009. Effects of dredging operations on sediment quality: contaminant 
mobilization in dredged sediments from the Port of Santos, SP, Brazil. J. Soils Sediments 9 (5), 420-432.

Turekian, K.K., Wedepohl, K.H., 1961. Distribution of the elements in some major units of the Earth's crust. Geol. Soc. Am. Bull. 72, 175-192.

USEPA, 1999. Screening level ecological risks assessment protocol for hazardous waste combustion facilities. Appendix E: Toxicity Reference Values. EPA 530-D99-001C vol. 3 (http://www.epa.gov/epaoswer/hazwaste/combust/eco-risk/voume3/a ppx-e.pdf).

Van Den Hurk, P., Eertman, R.H.M., Stronkhorst, J., 1997. Toxicity of harbour canal sediments before dredging and after off-shore disposal. Mar. Pollut. Bull. 34 (4), $244-249$.

Vandevivere, P.C., Bianchi, R., Verstraete, W., 1998. Review treatment and reuse of wastewater from the textile wet-processing industry : review of emerging technologies. J. Chem. Technol. Biotechnol. 72, 289-302.

Walker, W.J., Mcnutt, R.P., Mash, C.K., 1999. The potential contribution of urban runoff to surface sediments of the Passaic River: sources and chemical characteristics. Chemosphere 38 (2), 363-377.

Walkley-Black, C.A., 1965. Chemical and microbiological properties, in soil science society of America. Methods of soil analysis vol. 2, pp. 1372-1378 (ASA, Madison, WI, U.S.A).

Warnken, K.W., Gill, G.A., Griffin, L.L., Santschi, P.H., 2001. Sediment-water exchange of Mn, Fe, Ni and Zn in Galveston Bay, Texas. Mar. Chem. 73 (3-4), 215-231.
Wise, A., O'Brien, K., Woodruff, T., 2011. Are oral contraceptives a significant contributor to the estrogenicity of drinking water? Environ. Sci. Technol. 45, 51-60.

Yang, Jing, Chen, Ling, Liu, Li-zao, Shi, Wei-ling, Meng, X., 2014. Ecotoxicology and environmental safety comprehensive risk assessment of heavy metals in lake sediment from public parks in Shanghai. Ecotoxicol. Environ. Saf. 102, 129-135.

Zagatto, P.A., Bertoletti, E., 2008. Ecotoxicologia Aquática: Princípios e Aplicações. $2^{a}$ ed Rima, São Carlos-SP (486 pp.).

Zalmon, I.R., Macedo, I.M., Rezende CE, Falcão, A.P.C. Almeida, T.C 2013 . Estuarine, coastal and shelf science. The distribution of macrofauna on the inner continental shelf of southeastern Brazil: The major in fluence of an estuarine system. Estuar. Coast. Shelf Sci. 130, 169-178 (1)

Zonta, R., Guerzoni, S., Pérez-Ruzafa, A., Jonge, V.N., 2007. Measuring and managing changes in estuaries and lagoons : morphological and eco-toxicological aspects. Mar. Pollut. Bull. 55, 403-406.

Zonta, R., Zaggia, L., Argese, E., 1994. Heavy metal and grain-size distributions in estuarine shallow water sediments of the Cona Marsh (Venice Lagoon, Italy). Sci. Total Environ. 151 (1), 19-28. 